\title{
TGF- $\beta 1$ promotes the osteoinduction of human osteoblasts via the PI3K/AKT/mTOR/S6K1 signalling pathway
}

\author{
ZHAODONG ZHANG $^{1 *}$, XIUZHI ZHANG ${ }^{1,2^{*}}$, DEWEI ZHAO ${ }^{1}$, BAOYI LIU $^{1}$, BENJIE WANG $^{1}$, WEITING YU ${ }^{1}$, \\ JUNLEI LI ${ }^{1,2}$, XIAOBING YU ${ }^{1,2}$, FANG CAO ${ }^{3}$, GUOSHUANG ZHENG ${ }^{1}$, YAO ZHANG ${ }^{1}$ and YUPENG LIU ${ }^{1}$ \\ ${ }^{1}$ Department of Orthopaedics, The Affiliated Zhongshan Hospital of Dalian University, Dalian, Liaoning 116001; \\ ${ }^{2}$ Department of Special Materials and Devices, Institute of Metal Research, Chinese Academy of Science, \\ Shenyang, Liaoning 110016; ${ }^{3}$ Department of Biomedical Engineering, Faculty of Electronic Information \\ and Electrical Engineering, Dalian University of Technology, Dalian, Liaoning 116024, P.R. China
}

Received July 9, 2018; Accepted March 6, 2019

DOI: $10.3892 / \mathrm{mmr} .2019 .10051$

\begin{abstract}
Transforming growth factor $\beta 1$ (TGF- $\beta 1$ ) has been suggested to be a candidate cytokine in the field of bone tissue engineering. Cytokines serve important roles in tissue engineering, particularly in the repair of bone damage; however, the underlying molecular mechanisms remain unclear. In the present study, the effects of TGF- $\beta 1$ on the osteogenesis and motility of hFOB1.19 human osteoblasts were demonstrated via the phenotype and gene expression of cells. Additionally, the role of the phosphatidylinositol 3-kinase/protein kinase $\mathrm{B} /$ mammalian target of rapamycin/S6 kinase 1 (PI3K/AKT/mTOR/S6K1) signalling pathway in the effects of TGF- $\beta 1$ on osteoblasts was investigated. It was demonstrated using Cell Counting Kit- 8 and flow cytometry assays that the proliferation of human osteoblasts was promoted by $1 \mathrm{ng} / \mathrm{ml}$ TGF- $\beta 1$. In addition, alkaline phosphatase activity, Alizarin red staining, scratch-wound and Transwell assays were conducted. It was revealed that osteogenesis and the migration of cells were regulated by TGF- $\beta 1$ via the upregulation of osteogenic and migration-associated genes. Alterations in the expression of osteogenesis- and migration-associated genes were evaluated following pre-treatment with a PI3K/AKT inhibitor (LY294002) and an mTOR/S6K1 inhibitor (rapamycin), with or without TGF- $\beta 1$. The results indicated that TGF- $\beta 1$ affected the osteogenesis and mineralisation of osteoblasts via the PI3K/AKT signalling pathway. Furthermore, TGF- $\beta 1$ exhibited effects on mTOR/S6K1 downstream of PI3K/AKT. The
\end{abstract}

Correspondence to: Professor Dewei Zhao, Department of Orthopaedics, The Affiliated Zhongshan Hospital of Dalian University, 6 Jiefang Street, Dalian, Liaoning 116001, P.R. China E-mail: zhaodewei2016@163.com

*Contributed equally

Key words: transforming growth factor $\beta 1$, osteoinduction, phosphatidylinositol 3-kinase, protein kinase B, mammalian target of rapamycin, S6 kinase 1 present study demonstrated that TGF- $\beta 1$ promoted the proliferation, differentiation and migration of human hFOB1.19 osteoblasts, and revealed that TGF- $\beta 1$ affected the biological activity of osteoblasts via the PI3K/AKT/mTOR/S6K1 signalling pathway. Our findings may provide novel insight to aid the development of bone tissue engineering methods for the treatment of bone injury.

\section{Introduction}

The development of tissue engineering has aided the identification of novel approaches in the repair and treatment of bone damage. The bone tissue engineering process for repair involves the growth of seed cells using scaffold materials, frequently in the presence of cytokines, to generate tissue-engineered bone, and its potential use in clinical settings has been investigated $(1,2)$. At present, the development of orthopaedic tissue engineering scaffolds is progressing rapidly, with the production of porous tantalum, degradable magnesium, hydroxyapatite and high polymer materials (3). Scaffolds provide seed cells a spatial structure for adhesion, proliferation and differentiation, and regulate tissue regeneration and reconstruction $(1,4,5)$.

Growth factors are biologically active cytokines that stimulate the growth of cells. The binding of growth factors to cell membrane receptors is a specific, high-affinity process that regulates the growth and development of cells. Growth factors are used to promote the bone formation ability of an implant via surface modifications without altering the overall physical properties of the implant, thereby regulating the bone-repair microenvironment. For example, bone morphogenetic protein 2 (BMP-2) is frequently used for surface modification studies in implants and is used primarily in the treatment of fresh fractures, bone defects and avascular necrosis of the femoral head (6). It was demonstrated that BMP-2 promoted the proliferation, migration and osteogenic differentiation of mesenchymal stem cells (MSC), and induced bone formation in vivo $(7,8)$. In addition, vascular endothelial growth factor (VEGF), an important regulator of vascular development and angiogenesis, serves a crucial role in skeletal development. Poh et al (9) immobilised VEGF on the surface of titanium 
alloys. VEGF-modified implants increased the survival and proliferation of endothelial cells, and promoted the differentiation of human MSCs into endothelial cells, aiding angiogenesis and the formation of novel bone tissue $(10,11)$. These studies demonstrated that the use of growth factors to modify the surface of the implant promoted the osteointegration of the implant material.

Transforming growth factor $\beta 1$ (TGF- $\beta 1)$ is the most abundant cytokine in bone cells (12). Osteoblasts secrete large quantities of TGF- $\beta 1$, which serves an important role in the process of bone turnover (13). A member of the TGF- $\beta$ superfamily, TGF- $\beta 1$, promotes the proliferation and osteogenic differentiation of bone cells $(14,15)$. Additionally, it exhibits a notable chemotactic effect on human osteoblasts; this effect is particularly evident at low concentrations of TGF- $\beta 1$ (16). It was demonstrated that TGF- $\beta 1$ promoted the absorption of osteoclasts, and that novel bone formation was stimulated by in vivo injection of TGF- $\beta 1$. Furthermore, it was revealed that TGF- $\beta 1$ released by osteoclasts stimulated novel bone formation and reduced the extent of subsequent bone resorption (17). TGF- $\beta 1$ may exhibit therapeutic potential in wound healing (18). Previously, Chen et al (19) applied TGF- $\beta 1$ to porous titanium loaded with gelatine microspheres, and observed that TGF- $\beta 1$ promoted the adhesion, proliferation and differentiation of MG63 osteosarcoma cells. Lamberg et al (20) demonstrated that the localised delivery of TGF- $\beta 1$ enhanced the stability of titanium implants and promoted attachment. TGF- $\beta 1$ has received increasing attention regarding the modification of scaffold materials.

TGF- $\beta 1$ is involved in a series of physiological and biochemical processes, due to the complexity of its regulation of cell biological activity and the levels of protein phosphorylation observed in numerous associated signalling pathways. TGF- $\beta$ signalling pathways typically involve TGF- $\beta$ receptor-mediated suppressor of mothers against decapentaplegic (Smad)-dependent or -independent signalling (21). The former promotes the proliferation, chemotaxis and differentiation of bone cells, and reduces the secretion of receptor activator of nuclear factor $\kappa$-B ligand/osteoprotegerin via TGF- $\beta$-Smad signalling to inhibit osteoclast differentiation (22). The latter affects osteoblasts via mitogen-activated protein kinase (MAPK) kinase (MKK)-p38MAPK or MKK-extracellular signal-regulated kinase 1/2 signalling (23). TGF- $\beta$ suppresses Runt-related transcription factor 2 (Runx2) to inhibit the differentiation of osteoblasts (24). Furthermore, an association between the TGF- $\beta$ family and the phosphatidylinositol 3-kinase/protein kinase B (PI3K/AKT) signalling pathway has been reported (25). The PI3K/AKT signalling pathway has been identified as important in the survival, growth, proliferation and differentiation of cells (21-23). A recent study reported that inhibition of the PI3K/AKT signalling pathway promoted osteoblast injury (26). Additionally, PI3K/AKT activity promotes cell survival via the downstream mTOR pathway and participates in the metabolism, proliferation and angiogenesis of cells $(27,28)$.

At present, the effects of TGF- $\beta 1$ signalling on the migration and mineralisation of human osteoblasts remain unclear. In the present study, the effects of TGF- $\beta 1$ on osteoblast migration and mineralisation were investigated and the role of the $\mathrm{PI} 3 \mathrm{~K} / \mathrm{AKT} / \mathrm{mTOR} / \mathrm{S} 6 \mathrm{~K} 1$ signalling pathway was determined.

\section{Materials and methods}

Cell culture. Human foetal osteoblast hFOB1.19 cells (American Type Culture Collection, Manassas, VA, USA) were incubated at $37^{\circ} \mathrm{C}$ with $5 \% \mathrm{CO}_{2}$ and cultured in Dulbecco's Modified Eagle's medium (DMEM; HyClone; GE Healthcare Life Sciences, Logan, UT, USA) supplemented with $10 \%$ fetal bovine serum (HyClone; GE Healthcare Life Sciences), $100 \mu \mathrm{g} / \mathrm{ml}$ streptomycin and $100 \mathrm{IU} / \mathrm{ml}$ penicillin. Cells of passages 3-6 were selected for experiments.

Cell proliferation assay. hFOB1.19 osteoblasts $\left(5 \times 10^{3}\right.$ cells/well) were cultured in a 96-well plate for $24 \mathrm{~h}$ at $37^{\circ} \mathrm{C}$. Then, the medium was replaced and supplemented with TGF- $\beta 1(0,0.5,1,2,5$ and $10 \mathrm{ng} / \mathrm{ml}$; PeproTech China, Suzhou, China). Following incubation at $37^{\circ} \mathrm{C}$ for 1,3 or 5 days, $10 \mu \mathrm{l}$ Cell Counting Kit-8 (CCK-8) reagent (Dojindo Molecular Technologies, Inc., Kumamoto, Japan) was added to wells. Following incubation for a further $2 \mathrm{~h}$ at $37^{\circ} \mathrm{C}$, the absorbance at $450 \mathrm{~nm}$ was detected (650 nm reference) using an iMark $^{\mathrm{TM}}$ microplate reader (Bio-Rad Laboratories, Inc., Hercules, CA, USA).

Cell cycle measurement by fluorescence-activated cell sorting. hFOB1.19 human osteoblasts $\left(5 \times 10^{4}\right.$ cells/well) were cultured in a 6 -well plate for $24 \mathrm{~h}$ at $37^{\circ} \mathrm{C}$. Then, the medium was replaced and supplemented with TGF- $\beta 1(0,0.5,1,2,5$ and $10 \mathrm{ng} / \mathrm{ml}$ ) for $24 \mathrm{~h}$ at $37^{\circ} \mathrm{C}$. The cells were subsequently washed with PBS, removed by $0.25 \%$ trypsin/EDTA solution for $5 \mathrm{~min}$ at $37^{\circ} \mathrm{C}$ and centrifuged at $282 \mathrm{x} \mathrm{g}$ for $5 \mathrm{~min}$ at room temperature. Subsequently, cells were washed twice with PBS and fixed in $70 \%$ ethanol for $\geq 1 \mathrm{~h}$ at $-20^{\circ} \mathrm{C}$. They were washed twice to remove the ethanol, and propidium iodide/RNase Staining Buffer (BD Biosciences, Franklin Lakes, NJ, US) was added to the cells. Following incubation for $15 \mathrm{~min}$ at $37^{\circ} \mathrm{C}$, cells were analyzed using a flow cytometer (BD FACSDiva software; version 7.0; BD Biosciences) within $1 \mathrm{~h}$. The DNA content of cells was measured by flow cytometry to determine the cell cycle stage of cells.

Alkaline phosphatase (ALP) staining. ALP staining was performed to evaluate osteoblastogenic activity (29). hFOB1.19 osteoblasts $\left(5 \times 10^{4}\right.$ cells/well) were cultured in a 6-well plate and treated with TGF- $\beta 1(0,0.5,1,2,5$ and $10 \mathrm{ng} / \mathrm{ml})$, in the presence or absence of a PI3K/AKT inhibitor (10 $\mu$ M LY294002; PeproTech, Inc., Rocky Hill, NJ, USA) or an inhibitor of mammalian target of rapamycin/S6 kinase 1 (mTOR/S6K1; $100 \mathrm{nM}$ rapamycin) (30). Following incubation for 7 days at $37^{\circ} \mathrm{C}$, osteoblasts were washed with PBS two times, fixed in $4 \%$ paraformaldehyde (PFA) for $10 \mathrm{~min}$ at room temperature and washed with deionised water twice. Cells were incubated with a 5-bromo-4-chloro-3indolyl-phosphate/nitro blue tetrazolium (BCIP/NBT) ALP colour development kit (Beyotime Institute of Biotechnology, Haimen, China) for $1 \mathrm{~h}$ at $37^{\circ} \mathrm{C}$ and washed with deionised water two times. Then, images were acquired using a phase contrast microscope equipped with a charge-coupled device (CCD) camera (magnification, x100). Image-Pro Plus 6.0 (Media Cybernetics, Inc., Rockville, MD, USA) was used to evaluate the percentage of the total stained area. 
Alizarin red S staining. Alizarin red S staining was performed to evaluate the extent of $\mathrm{Ca}^{2+}$ deposition in the extracellular matrix. hFOB1.19 human osteoblasts $\left(5 \times 10^{4}\right.$ cells/well $)$ were cultured in a 6-well plate and treated with TGF- $\beta 1(0.5,1,2$, 5 and $10 \mathrm{ng} / \mathrm{ml}$ ), with or without $10 \mu \mathrm{M} \mathrm{LY} 294002$ or $100 \mathrm{nM}$ rapamycin. Negative control (NC) cells were not treated with the compounds. Following incubation for 14 days at $37^{\circ} \mathrm{C}$, osteoblasts were rinsed with PBS twice, fixed in $4 \%$ PFA for $10 \mathrm{~min}$ at room temperature and washed with deionised water twice. Cells were incubated with $1 \%$ (w/v) Alizarin red at $\mathrm{pH} 4.4$ for $40 \mathrm{~min}$ at $37^{\circ} \mathrm{C}$ and subsequently washed with deionised water two times. Then, images were captured using a CCD camera-equipped phase contrast microscope (magnification, x100). The Alizarin-positive area was evaluated as a percentage of the total area using Image-Pro Plus 6.0.

Transwell assay. A migration assay was conducted using 24-well Transwell inserts (8- $\mu \mathrm{m}$ pores; Costar; Corning, Inc., Corning, NY, USA). The cells were treated with TGF- $\beta 1$ $(0,0.5,1,2,5$ and $10 \mathrm{ng} / \mathrm{ml})$, with or without $10 \mu \mathrm{M} \mathrm{LY} 294002$ or $100 \mathrm{nM}$ rapamycin. In the assay, $5 \times 10^{3} \mathrm{hFOB} 1.19$ osteoblast cells cultured with DMEM containing 0.1\% FBS $(200 \mu \mathrm{l})$ were seeded in the upper chambers, and DMEM containing $1 \%$ FBS (HyClone; GE Healthcare Life Sciences) (500 $\mu 1)$ was added to the lower chambers. Following incubation for $24 \mathrm{~h}$ at $37^{\circ} \mathrm{C}$, the cells on the upper surface of the membrane were gently removed using a cotton swab. Cells penetrating to the lower surface of the inserts were fixed with methanol for $10 \mathrm{~min}$ at room temperature, stained with $0.1 \%$ crystal violet for $10 \mathrm{~min}$ at room temperature and counted using a light microscope (magnification, x100). Five randomly-selected fields were used to count the migrating cells in each well. Data are presented as the mean \pm standard error of the mean for five randomly-selected fields per sample. Assays were independently performed in triplicate.

Scratch-wound assay. hFOB1.19 osteoblasts ( $5 \times 10^{4}$ cells/well) were cultured in a 6 -well plate and treated with TGF- $\beta 1$ $(0,0.5,1,2,5$ or $10 \mathrm{ng} / \mathrm{ml})$, with or without $10 \mu \mathrm{M}$ LY294002 or $100 \mathrm{nM}$ rapamycin at $37^{\circ} \mathrm{C}$ with $5 \% \mathrm{CO}_{2}$. The cell layer was wounded using a $200-\mu 1$ pipette tip. The scratched wells were washed with PBS three times and cultured in serum-free medium for $24 \mathrm{~h}$ at $37^{\circ} \mathrm{C}$. The initial wounding and cell movement in the scratched area were monitored using a CCD camera-equipped phase contrast microscope (magnification, $\mathrm{x} 100)$ to quantify the number of cells that had migrated into the wounded area within $24 \mathrm{~h}$.

Reverse transcription-quantitative polymerase chain reaction $(R T-q P C R)$. hFOB1.19 human osteoblasts $\left(5 \times 10^{4}\right.$ cells/well) were cultured in a 6 -well plate and treated with $1 \mathrm{ng} / \mathrm{ml}$ TGF- $\beta 1,10 \mu \mathrm{M}$ LY294002 and/or $100 \mathrm{nM}$ rapamycin. Following incubation for 14 days, total RNA isolation was performed using an RNeasy Mini kit (Qiagen, Inc., Valencia, CA, USA), according to the manufacturer's protocols. The purity and concentration of RNA was determined via spectrophotometry at $260 \mathrm{~nm}$ and 260/280 nm. The extracted RNA was reverse transcribed using a PrimeScript $^{\mathrm{TM}}$ II first Strand cDNA Synthesis kit (Takara Biotechnology Co., Ltd., Dalian, China). RT reactions were
Table I. Primer sequences for Osterix, Runx2, OC, OPN, MMP-2, MMP-9 and $\beta$-actin.

\begin{tabular}{|c|c|}
\hline Gene & Sequence \\
\hline Osterix & $\begin{array}{l}\text { Forward: 5'-GCGGCAAGGTGTATGGCAAGG-3' } \\
\text { Reverse: 5'-GCAGAGCAGGCAGGTGAACTTC-3' }\end{array}$ \\
\hline Runx2 & $\begin{array}{l}\text { Forward: 5'-AACAGCAGCAGCAGCAGCAG-3' } \\
\text { Reverse: 5'-GCACCGAGCACAGGAAGTTGG-3' }\end{array}$ \\
\hline OCN & $\begin{array}{l}\text { Forward: 5'-CAGGCGCTACCTGTATCAATGGC-3' } \\
\text { Reverse: 5'-GCCGATGTGGTCAGCCAACTC-3' }\end{array}$ \\
\hline OPN & $\begin{array}{l}\text { Forward: 5'-AGCGAGGAGTTGAATGGTGCATAC-3' } \\
\text { Reverse: 5'-AATCTGGACTGCTTGTGGCTGTG-3' }\end{array}$ \\
\hline MMP-2 & $\begin{array}{l}\text { Forward: 5'-GCCTCTCCTGACATTGACCTTGG-3' } \\
\text { Reverse: 5'-CACCACGGATCTGAGCGATGC-3' }\end{array}$ \\
\hline MMP-9 & $\begin{array}{l}\text { Forward: 5'-TCCTGGTGCTCCTGGTGCTG-3' } \\
\text { Reverse: 5'-CTGCCTGTCGGTGAGATTGGTTC-3' }\end{array}$ \\
\hline$\beta$-actin & $\begin{array}{l}\text { Forward: 5'-AGCCATGTACGTTGCTATCCA-3' } \\
\text { Reverse: 5'-ACCGGAGTCCATCACGATG-3' }\end{array}$ \\
\hline
\end{tabular}

MMP, matrix metalloproteinase; OCN, osteocalcin; OPN, osteopontin; Osterix, transcription factor Sp7; Runx2, Runt-related transcription factor 2.

performed using a RT-qPCR System (Eppendorf, Hamburg, Germany) with the following thermocycling conditions: $10 \mathrm{~min}$ at $37^{\circ} \mathrm{C}, 30 \mathrm{~min}$ at $42^{\circ} \mathrm{C}$ and $5 \mathrm{~min}$ at $95^{\circ} \mathrm{C}$ The primers [transcription factor $\mathrm{Sp} 7$ (Osterix), Runx2, osteocalcin (OCN), osteopontin (OPN), matrix metalloproteinase (MMP)-2, MMP-9 and $\beta$-actin] were synthesised by Sangon Biotech Co., Ltd. (Shanghai, China) and are presented in Table I. qPCR was conducted using an ABI QuantStudio ${ }^{\mathrm{TM}}$ 7 Flex (Applied Biosystems; Thermo Fisher Scientific, Inc., Waltham, MA, USA) and SYBR ${ }^{\circledR}$ Green PCR master mix (Thermo Fisher Scientific, Inc.). Reactions were incubated in a MicroAmp ${ }^{\circledR}$ 96-well reaction plate (Thermo Fisher Scientific, Inc.) at $95^{\circ} \mathrm{C}$ for $10 \mathrm{~min}$, followed by 40 cycles at $95^{\circ} \mathrm{C}$ for $15 \mathrm{sec}$ and at $60^{\circ} \mathrm{C}$ for $1 \mathrm{~min} . \beta$-actin was used as an internal standard. Data were analysed using QuantStudio Real-Time PCR Software (version 2.1; Thermo Fisher Scientific, Inc.). mRNA expression levels were normalised to $\beta$-actin and calculated using the $2^{-\Delta \Delta C q}$ method (31). All samples were analysed three times.

Western blot analysis. Osteoblasts were inoculated into 10-cm culture dishes. Following culture for 3 days at $37^{\circ} \mathrm{C}$ with $5 \%$ $\mathrm{CO}_{2}$, cells were treated with $1 \mathrm{ng} / \mathrm{ml}$ TGF- $\beta 1$ or untreated. The cells were incubated for $24 \mathrm{~h}$ and then washed three times with $4^{\circ} \mathrm{C}$ PBS for phosphatase inhibition. A mixture of the PBS, protease inhibitor and radioimmunoprecipitation assay lysate (Sigma-Aldrich; Merck KGaA, Darmstadt, Germany) was used to extract total protein from the cells. Total protein concentration was determined using a Bradford assay kit (Sangon Biotech Co., Ltd.). All samples were mixed with 5X loading buffer and boiled in water at $100^{\circ} \mathrm{C}$ for $10 \mathrm{~min}$. A total of $15 \mu \mathrm{g}$ protein was loaded in each lane. Proteins were separated by $2 \%$ SDS-PAGE for $2 \mathrm{~h}$ and transferred to $0.2-\mu \mathrm{m}$ polyvinylidene difluoride (PVDF) membranes (EMD Millipore, Billicera, MA, USA) at $80 \mathrm{~V}$ for $1 \mathrm{~h}$. Following blocking 


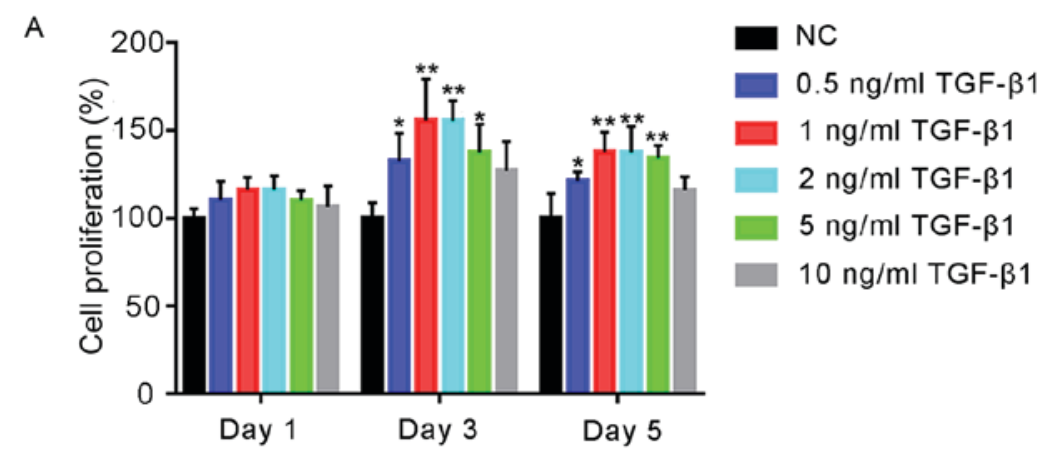

\begin{tabular}{clll}
\hline TGF- $\beta 1$ & \multicolumn{1}{c}{ Day 1 } & \multicolumn{1}{c}{ Day 3 } & \multicolumn{1}{c}{ Day 5 } \\
\hline $\mathrm{NC}$ & $100 \pm 5.7 \%$ & $100 \pm 8.7 \%$ & $100 \pm 14.0 \%$ \\
$0.5 \mathrm{ng} / \mathrm{ml}$ & $110 \pm 10.6 \%$ & $132 \pm 16.0 \%$ * & $121 \pm 5.4 \% *$ \\
$1 \mathrm{ng} / \mathrm{ml}$ & $116 \pm 7.1 \%$ & $156 \pm 23.5 \%$ ** & $138 \pm 11.4 \%$ ** \\
$2 \mathrm{ng} / \mathrm{ml}$ & $116 \pm 8.0 \%$ & $155 \pm 11.4 \% * *$ & $137 \pm 14.8 \% * *$ \\
$5 \mathrm{ng} / \mathrm{ml}$ & $110 \pm 5.6 \%$ & $138 \pm 16.1 \%$ * & $134 \pm 7.3 \% * *$ \\
$10 \mathrm{ng} / \mathrm{ml}$ & $107 \pm 11.8 \%$ & $127 \pm 16.9 \%$ & $116 \pm 7.7 \%$ \\
\hline
\end{tabular}
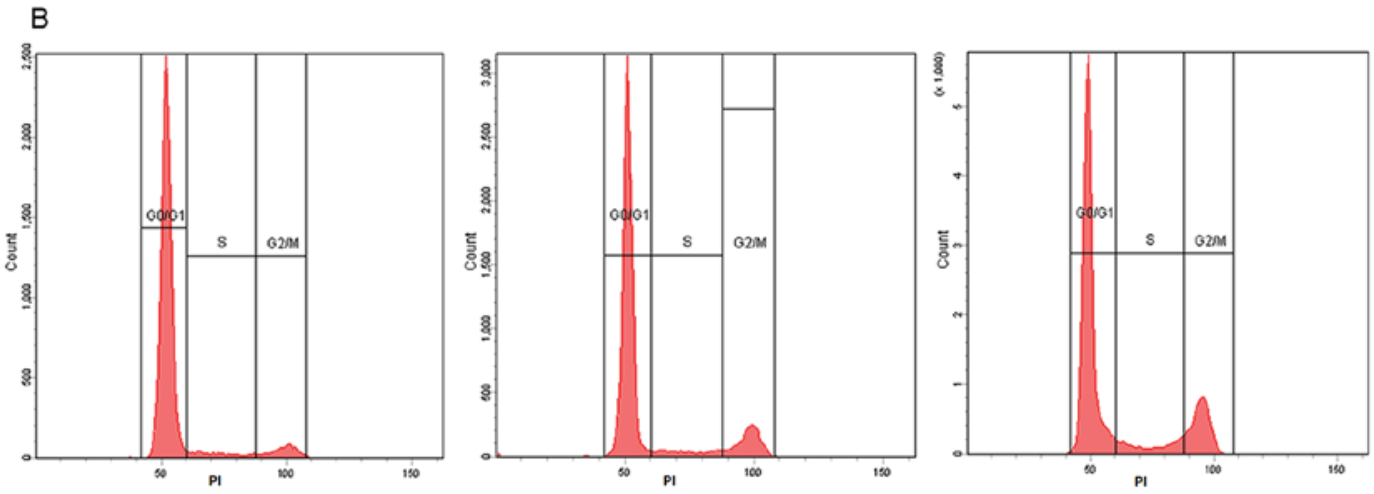

NC

$0.5 \mathrm{ng} / \mathrm{ml}$ TGF- $\beta 1$
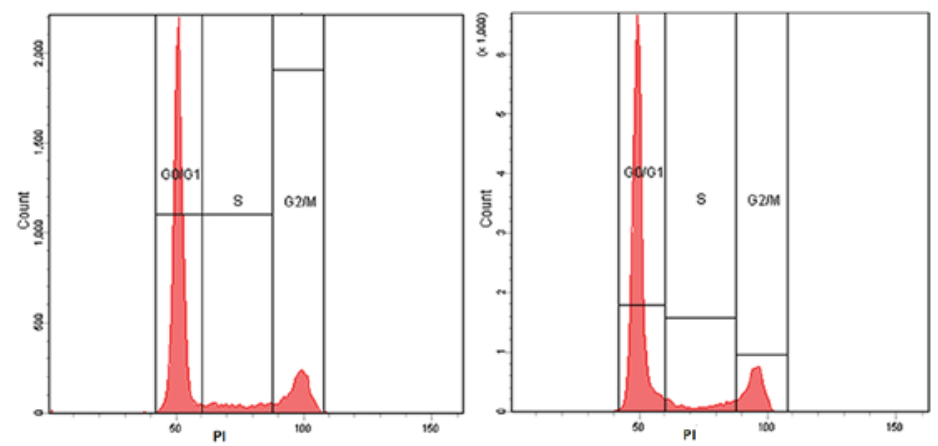

$1 \mathrm{ng} / \mathrm{ml}$ TGF- $\beta 1$

$2 \mathrm{ng} / \mathrm{ml}$ TGF- $\beta 1$

$5 \mathrm{ng} / \mathrm{ml}$ TGF- $\beta 1$

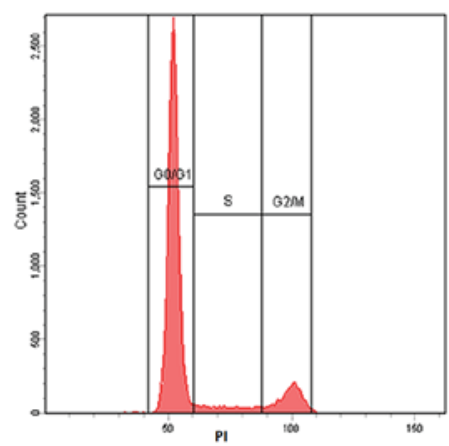

10 ng/ml TGF- $\beta 1$

\begin{tabular}{|c|c|c|c|c|c|}
\hline TGF- $\beta 1$ & G0/G1 & & S & G2/M & \\
\hline $\mathrm{NC}$ & $83.41 \pm 3.90 \%$ & & $7.33 \pm 1.10 \%$ & $9.15 \pm 1.99 \%$ & \\
\hline $0.5 \mathrm{ng} / \mathrm{ml}$ & $77.32 \pm 2.52 \%$ & * & $7.83 \pm 1.31 \%$ & $14.55 \pm 2.19 \%$ & * \\
\hline $1 \mathrm{ng} / \mathrm{ml}$ & $70.82 \pm 3.19 \%$ & ** & $10.14 \pm 0.90 \%$ ** & $18.96 \pm 2.90 \%$ & *** \\
\hline $2 \mathrm{ng} / \mathrm{ml}$ & $71.54 \pm 2.22 \%$ & $\star \star$ & $10.45 \pm 1.06 \%$ ** & $17.74 \pm 0.82 \%$ & $\star \star \star$ \\
\hline $5 \mathrm{ng} / \mathrm{ml}$ & $75.73 \pm 3.33 \%$ & * & $8.60 \pm 1.30 \%$ & $15.62 \pm 1.47 \%$ & ** \\
\hline $10 \mathrm{ng} / \mathrm{ml}$ & $78.71 \pm 4.28 \%$ & & $8.01 \pm 1.29 \%$ & $12.91 \pm 3.22 \%$ & * \\
\hline
\end{tabular}

Figure 1. Effects of TGF- $\beta 1$ on the proliferation and cell cycle of human osteoblasts. (A) Proliferation of hFOB1.19 cells following treatment with various concentrations of TGF- $\beta 1$, as determined by a Cell Counting Kit- 8 assay. The absorbance was detected at $450 \mathrm{~nm}$. (B) Flow cytometry analysis of cell cycle distribution following treatment with various concentrations of TGF- $\beta 1$ for $24 \mathrm{~h}$. Data are presented as the mean \pm standard deviation. ${ }^{*} \mathrm{P}<0.05,{ }^{* * *} \mathrm{P}<0.01$ and ${ }^{* * * *} \mathrm{P}<0.001$ vs. NC. NC, negative control; PI, propidium iodide; TGF- $\beta 1$, transforming growth factor $\beta 1$.

for $1.5 \mathrm{~h}$ at room temperature in $3 \%$ bovine serum albumin (Sigma-Aldrich; Merck KGaA) in PBS, membranes were cut according to the molecular weight of the pre-stained marker protein and incubated overnight at $4^{\circ} \mathrm{C}$ with the following 
A
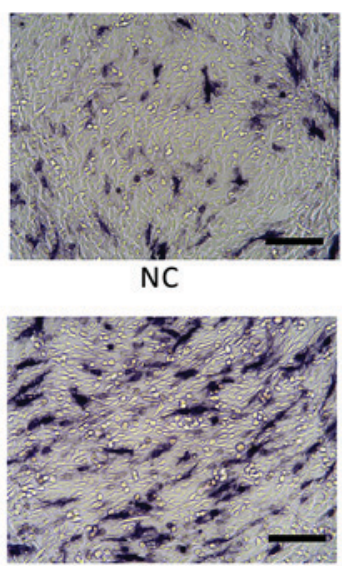

$2 \mathrm{ng} / \mathrm{ml} \mathrm{TGF}-\beta 1$

B

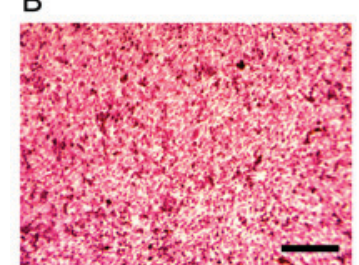

NC

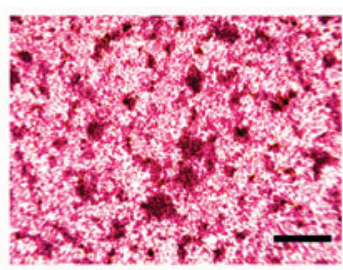

$2 \mathrm{ng} / \mathrm{ml} \mathrm{TGF-} \beta 1$
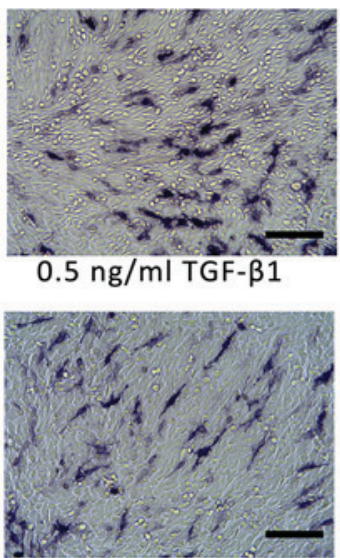

$5 \mathrm{ng} / \mathrm{ml} \mathrm{TGF}-\beta 1$

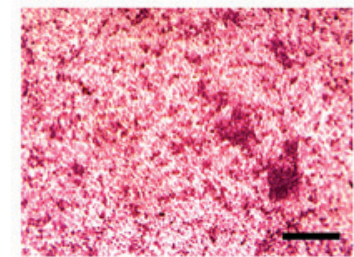

$0.5 \mathrm{ng} / \mathrm{ml} \mathrm{TGF- \beta 1}$

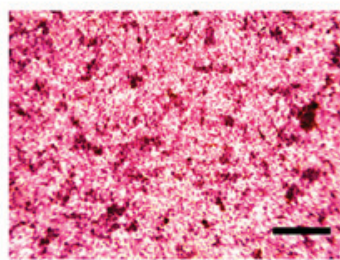

$5 \mathrm{ng} / \mathrm{ml} \mathrm{TGF}-\beta 1$
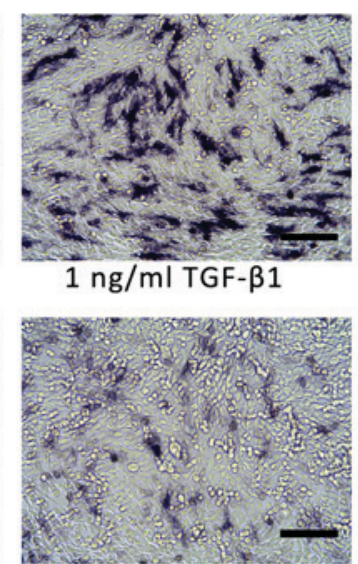

$10 \mathrm{ng} / \mathrm{ml} \mathrm{TGF}-\beta 1$

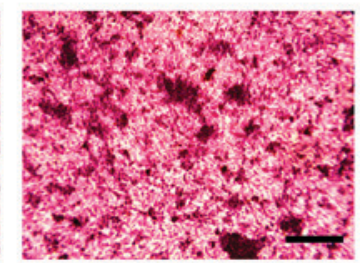

$1 \mathrm{ng} / \mathrm{ml} \mathrm{TGF}-\beta 1$

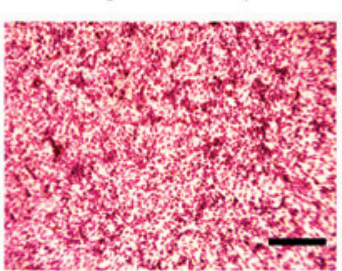

$10 \mathrm{ng} / \mathrm{ml}$ TGF- $\beta 1$
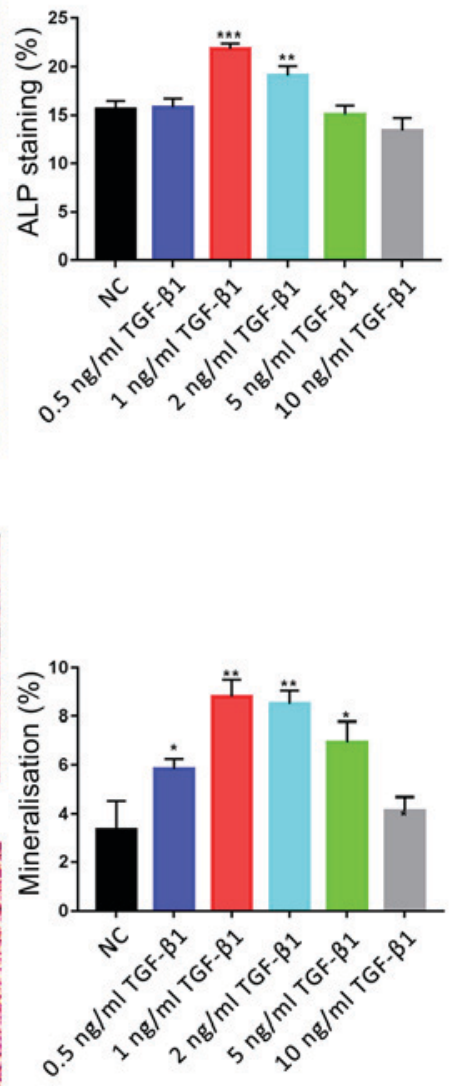

Figure 2. Effects of TGF- $\beta 1$ on ALP activity and the mineralisation of osteoblasts. (A) Effects of treatment with various concentrations of TGF- $\beta 1$ for 7 days on the activity of ALP in hFOB1.19 human osteoblasts. ALP-positive cells were stained with 5-bromo-4-chloro-3-indolyl-phosphate/nitro blue tetrazolium. (B) $\mathrm{Ca}^{2+}$ deposits following treatment of osteoblasts with various concentrations of TGF- $\beta 1$ for 14 days were identified by Alizarin red S staining. Scale bar, $200 \mu \mathrm{m}$. Data are presented as the mean \pm standard deviation. ${ }^{*} \mathrm{P}<0.05,{ }^{* *} \mathrm{P}<0.01$ and ${ }^{* * *} \mathrm{P}<0.001$ vs. NC. ALP, alkaline phosphatase; NC, negative control; TGF- $\beta 1$, transforming growth factor $\beta 1$.

primary antibodies (all 1:1,000; Cell Signaling Technology, Inc., Danvers, MA, USA): PI3K (cat. no. D32A5); phosphorylated (p)-PI3K (cat. no. 4228T); AKT (cat. no. C67E7); p-AKT (cat. no. D9E); mTOR (cat. no. 7C10); p-mTOR (cat. no. D9C2) and GAPDH (cat. no. D16H11). The PVDF membranes were washed three times in TBS-Tween 20 (1xTBS, 0.1\% Tween 20) for $10 \mathrm{~min} /$ wash. Membranes were then incubated with a secondary antibody (anti-rabbit immunoglobulin G, horseradish peroxidase-labeled; cat no. 7074; 1:7,500; Cell Signaling Technology, Inc.) for $45 \mathrm{~min}$ at room temperature and washed three times with TBS-T (10 min/wash). Protein bands were visualised via enhanced chemiluminescence (Thermo Fisher Scientific, Inc.) and analysed via GIS gel image analysis system photography (Tanon Science and Technology Co., Ltd., Shanghai, China).

Statistical analyses. All experiments were repeated at least three times. Unless otherwise stated, all data were presented as the mean \pm standard deviation. Differences between groups were determined by performing analyses of variance followed by the Least Significant Difference multiple comparisons test. Data were analysed using SPSS version 20.0 for Windows
(IBM Corp., Armonk, NY, USA). $\mathrm{P}<0.05$ was considered to indicate a statistically significant difference.

\section{Results}

Effects of TGF- $\beta 1$ on the proliferation of hFOB1.19 human osteoblast cells. The effects of a range of concentrations of TGF- $\beta 1$ on the proliferation of hFOB1.19 human osteoblasts were determined after 1, 3 and 5 days of treatment (Fig. 1A). No significant differences were observed between the experimental groups following 1 day of treatment; however, by the third day of treatment, the proliferation of cells treated with TGF- $\beta 1(0.5,1,2$ and $5 \mathrm{ng} / \mathrm{ml})$ was significantly increased compared with the negative control (NC). Additionally, by day 5 , the proliferation of cells in the $0.5,1,2$ and $5 \mathrm{ng} / \mathrm{ml}$ TGF- $\beta 1$ groups was significantly increased compared with the NC group $(\mathrm{P}<0.05)$; however, no significant differences was reported following treatment for 5 days with $10 \mathrm{ng} / \mathrm{ml}$ TGF- $\beta 1$ ( $\mathrm{P}>0.05)$. Proliferation was most markedly increased in the 1 and $2 \mathrm{ng} / \mathrm{ml}$ TGF- $\beta 1$ groups; no significant difference was observed between the 1 and $2 \mathrm{ng} / \mathrm{ml}$ TGF- $\beta 1$-treatment groups $(\mathrm{P}>0.05)$. 

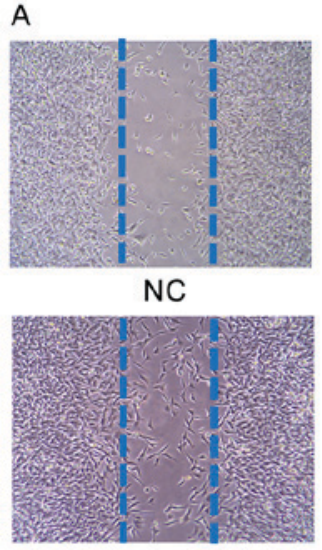

$2 \mathrm{ng} / \mathrm{ml} \mathrm{TGF}-\beta 1$

B

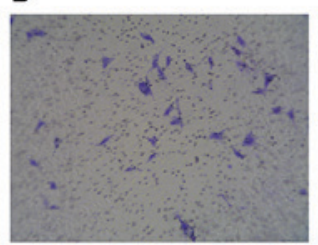

NC

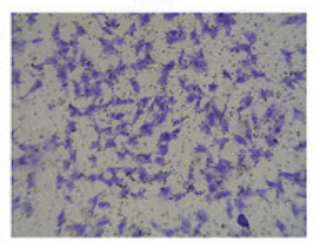

$2 \mathrm{ng} / \mathrm{ml} \mathrm{TGF- \beta 1}$
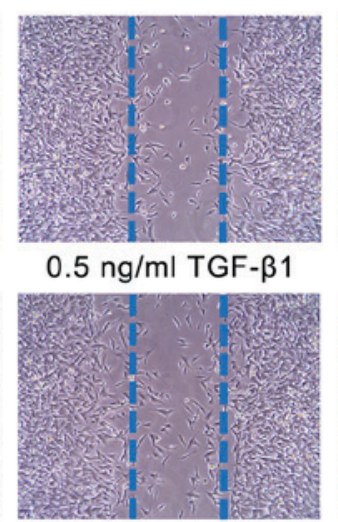

$5 \mathrm{ng} / \mathrm{ml} \mathrm{TGF- \beta 1}$

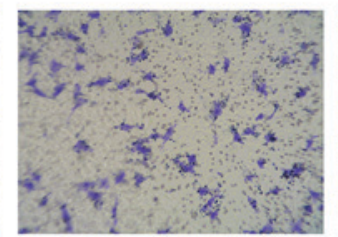

$0.5 \mathrm{ng} / \mathrm{ml} \mathrm{TGF}-\beta 1$

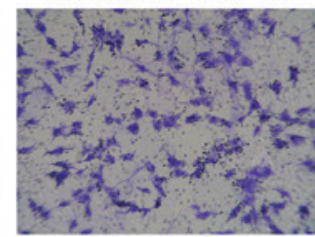

$5 \mathrm{ng} / \mathrm{ml}$ TGF- $\beta 1$

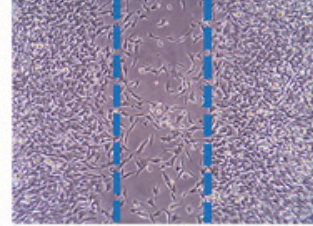

$1 \mathrm{ng} / \mathrm{ml}$ TGF- $\beta 1$

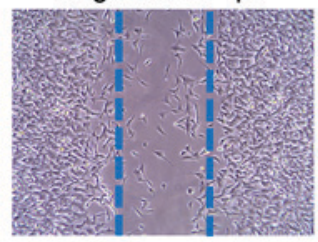

$10 \mathrm{ng} / \mathrm{ml}$ TGF- $\beta 1$

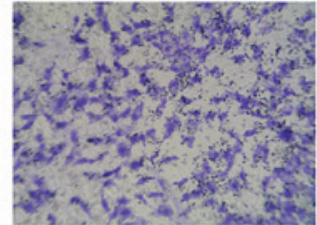

$1 \mathrm{ng} / \mathrm{ml}$ TGF- $\beta 1$

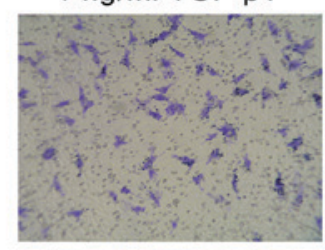

$10 \mathrm{ng} / \mathrm{ml} \mathrm{TGF-} \beta 1$
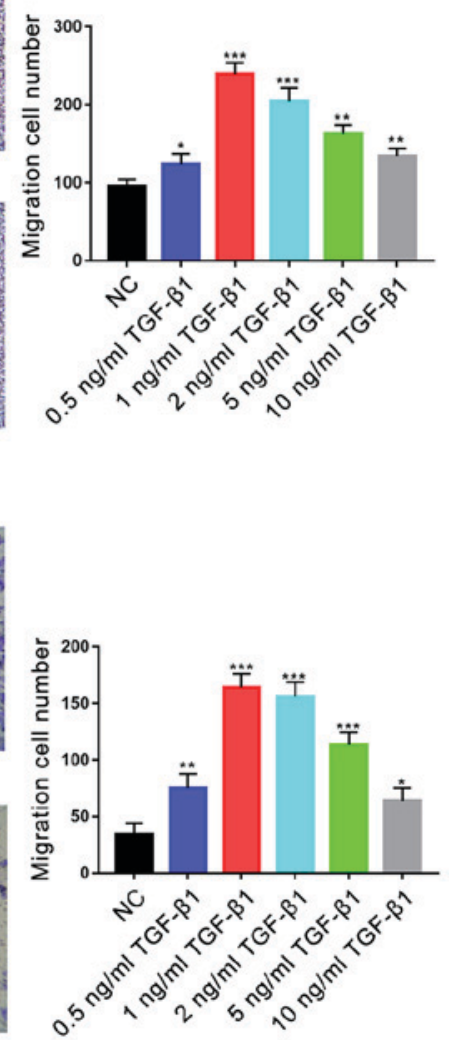

Figure 3. Effects of TGF- $\beta 1$ on the motility of human osteoblasts. (A) Migration of hFOB1.19 human osteoblasts treated with various concentrations of TGF- $\beta 1$ for $24 \mathrm{~h}$, as determined by a scratch-wound assay. The number of cells entering the wound indicated the migration of cells. (B) Migration of osteoblasts treated with various concentrations of TGF- $\beta 1$ for $24 \mathrm{~h}$, as determined by a Transwell assay. Scale bar, $200 \mu \mathrm{m}$. Data are presented as the mean \pm standard deviation. ${ }^{*} \mathrm{P}<0.05,{ }^{* *} \mathrm{P}<0.01$ and ${ }^{* * * *} \mathrm{P}<0.001$ vs. NC. NC, negative control; TGF- $\beta 1$, transforming growth factor $\beta 1$.

Effects on hFOB1.19 osteoblast cell cycle following TGF- $\beta 1$ treatment. The effects of various concentrations of TGF- $\beta 1$ on the hFOB1.19 cell cycle were analysed using flow cytometry. It was revealed that the proportion of osteoblasts in $\mathrm{G}_{0} / \mathrm{G}_{1}$ phase following treatment for $24 \mathrm{~h}$ with TGF- $\beta 1(0.5$, 1,2 and $5 \mathrm{ng} / \mathrm{ml}$ ) was significantly decreased compared with the control, whereas that in $\mathrm{G} 2 / \mathrm{M}$ phase was significantly increased $(\mathrm{P}<0.05 ;$ Fig. 1B). The increased percentage of $\mathrm{G} 2 / \mathrm{M}$ cells in the $1 \mathrm{ng} / \mathrm{ml}$ group was most notable. Treatment with $10 \mathrm{ng} / \mathrm{ml}$ TGF- $\beta 1$ did not significantly alter the proportion of cells in $G_{0} / G_{1}$ and $S$ phase $(P>0.05)$.

Effects of TGF- $\beta 1$ on osteogenic induction and the motility of hFOB1.19 cells. Osteoblasts were treated with various concentrations of TGF- $\beta 1(0,0.5,1,2,5$ and $10 \mathrm{ng} / \mathrm{ml})$, and the osteogenic activities and motility of cells were investigated using ALP and Alizarin red S staining, and scratch-wound and Transwell assays, respectively. ALP staining revealed that only 1 and $2 \mathrm{ng} / \mathrm{ml} \mathrm{TGF}-\beta 1$ significantly promoted ALP activity in osteoblasts compared with the control group ( $\mathrm{P}<0.01$; Fig. $2 \mathrm{~A})$. Additionally, Alizarin red $\mathrm{S}$ staining revealed that the degree of mineralisation was significantly increased following treatment with 1 and $2 \mathrm{ng} / \mathrm{ml}$ TGF- $\beta 1$ compared with the control group $(\mathrm{P}<0.01$; Fig. 2B). Furthermore, the degree of mineralisation was also significantly increased following treatment with 0.5 and $5 \mathrm{ng} / \mathrm{ml}$ TGF- $\beta 1(\mathrm{P}<0.05)$; no significant difference was reported between the $10 \mathrm{ng} / \mathrm{ml}$ TGF- $\beta 1$-treated and control groups.

Treatment with TGF- $\beta 1(0.5,1,2,5$ or $10 \mathrm{ng} / \mathrm{ml})$ resulted in significantly increased migration of cells in the scratch-wound assay at all concentrations compared with the control $(\mathrm{P}<0.05$; Fig. $3 \mathrm{~A})$; the greatest effects were observed in the 1 and $2 \mathrm{ng} / \mathrm{ml}$ TGF- $\beta 1$-treatment groups $(\mathrm{P}<0.001)$. Similarly, significantly increased migration was observed during the Transwell assay following treatment with all concentrations of TGF- $\beta 1$ compared with the control $(\mathrm{P}<0.05$; Fig. 3B), with the most significant increases observed in the 1 and $2 \mathrm{ng} / \mathrm{ml}$ TGF- $\beta 1$-treatment groups $(\mathrm{P}<0.001)$. No significant difference was reported between the migration of cells treated with 1 or $2 \mathrm{ng} / \mathrm{ml}$ TGF- $\beta 1(\mathrm{P}>0.05)$.

Effects of TGF- $\beta 1$-mediated PI3K/AKT signalling on ALP activity in osteoblasts. The effects of $1 \mathrm{ng} / \mathrm{ml}$ TGF- $\beta 1$ treatment on the activity of ALP in hFOB1.19 osteoblasts was investigated; ALP activity generates high concentrations of phosphate at mineral deposition sites during bone formation (5) and is a characteristic marker of active osteoblasts. ALP-positive osteoblasts are stained purple by BCIP/NBT (Fig. 4A). ALP staining revealed that treatment with $1 \mathrm{ng} / \mathrm{ml}$ TGF- $\beta 1$ for 7 days significantly promoted ALP activity in 
A

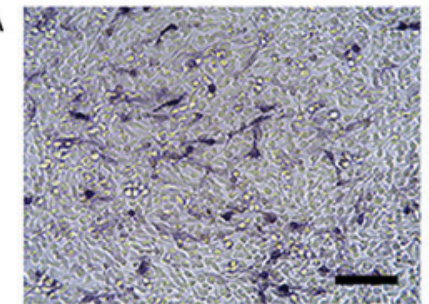

NC

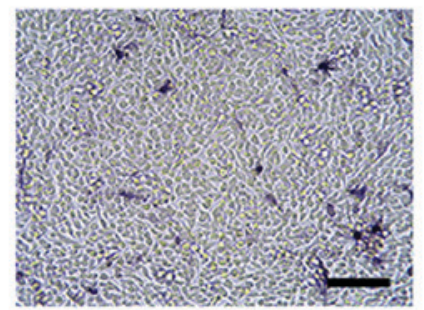

LY

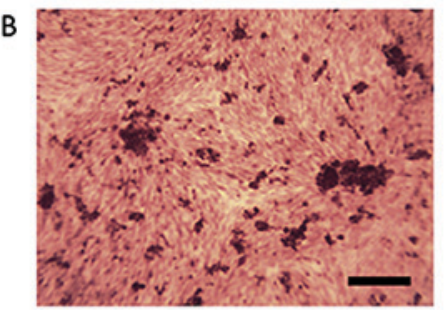

$\mathrm{NC}$

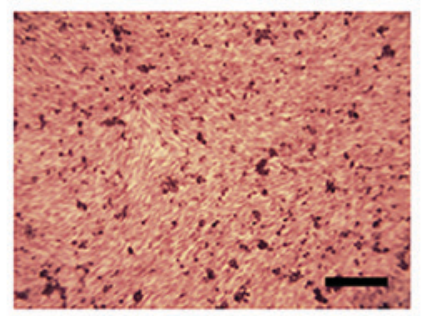

LY

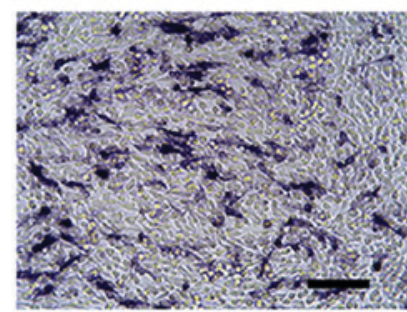

TGF- $\beta 1$

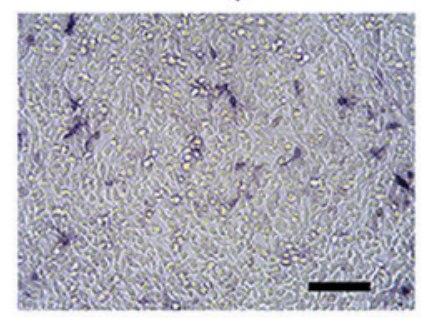

TGF- $\beta 1+L Y$

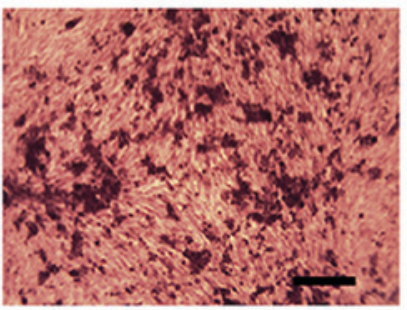

TGF- $\beta 1$

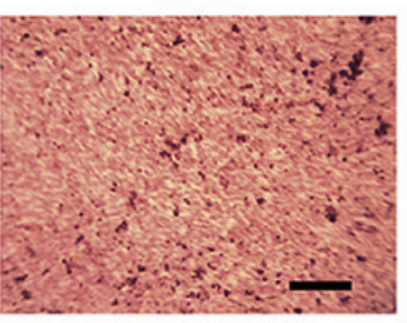

TGF- $\beta 1+L Y$
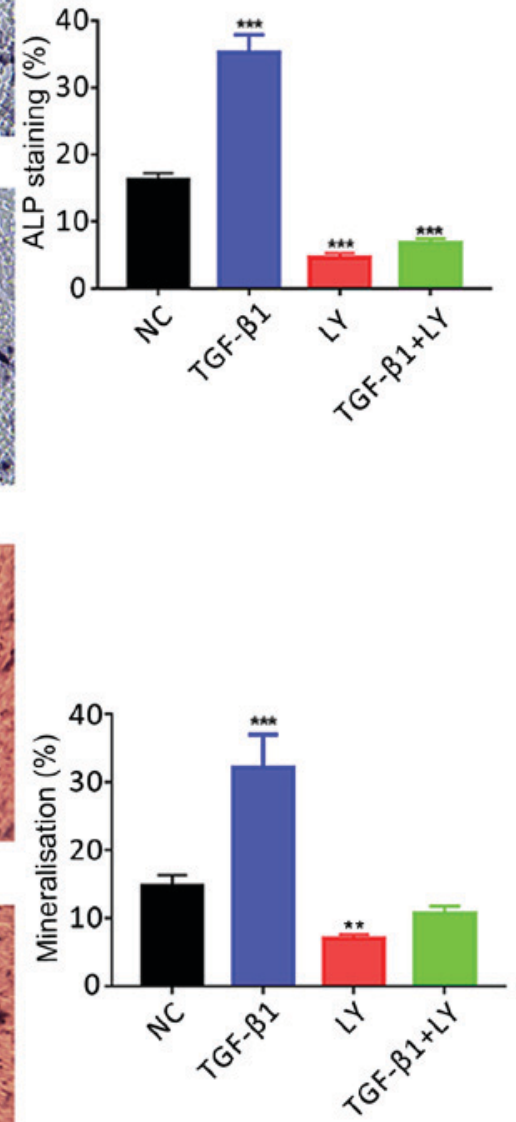

Figure 4. Effects of TGF- $\beta 1$ on osteogenic induction are dependent upon PI3K/AKT signalling. (A) Effects of treatment for 7 days with 1 ng/ml TGF- $\beta 1$ and/or $10 \mu \mathrm{MLY}$, a PI3K/AKT inhibitor, on the activity of ALP in hFOB1.19 human osteoblasts. ALP-positive cells were stained with 5-bromo-4-chloro-3-indolyl-phosphate/nitro blue tetrazolium. (B) $\mathrm{Ca}^{2+}$ deposits following treatment of osteoblasts for 14 days with $1 \mathrm{ng} / \mathrm{ml} \mathrm{TGF-} \beta 1$ and/or $10 \mu \mathrm{M} \mathrm{LY}$, identified by Alizarin red $\mathrm{S}$ staining. Scale bar, $200 \mu \mathrm{m}$. Data are presented as the mean \pm standard deviation. ${ }^{* *} \mathrm{P}<0.01$ and ${ }^{* * *} \mathrm{P}<0.001$ vs. NC. AKT, protein kinase B; ALP, alkaline phosphatase; LY, LY294002; NC, negative control; PI3K, phosphatidylinositol 3-kinase; TGF- $\beta 1$, transforming growth factor $\beta 1$.

human osteoblasts; however, significant reductions in ALP activity compared with the control were observed following treatment with the PI3K/AKT inhibitor LY294002 (10 $\mu \mathrm{M})$, in the presence or absence of TGF- $\beta 1(\mathrm{P}<0.001)$.

Effects of TGF- $\beta 1$-mediated PI3K/AKT signalling on osteoblast mineralisation. Mineralisation of the extracellular matrix serves an important role in the formation of bone (5). In the present study, it was demonstrated using Alizarin red $\mathrm{S}$ staining that the treatment of hFOB.19 osteoblasts with $1 \mathrm{ng} / \mathrm{ml}$ TGF- $\beta 1$ for 14 days significantly promoted the mineralisation of extracellular matrices compared with the control (Fig. 4B). Conversely, significant reductions in matrix $\mathrm{Ca}^{2+}$ deposits were reported following the inhibition of the PI3K/AKT signalling pathway via treatment with $10 \mu \mathrm{M}$ LY294002 compared with the NC group $(\mathrm{P}<0.01)$.

Effects of TGF- $\beta 1$-mediated PI3K/AKT signalling on the motility of osteoblasts. The role of TGF- $\beta 1$ in the migration of osteoblasts was investigated using a scratch-wound assay. It was revealed that the number of migrating cells following treatment with $1 \mathrm{ng} / \mathrm{ml}$ TGF- $\beta 1$ (364 \pm 11 cells) was significantly increased compared with the control (176 \pm 7 cells; Fig. 5A). Conversely, treatment with $10 \mu \mathrm{M}$ LY294002 (106 \pm 8 cells) or LY294002 plus TGF- $\beta 1$ (101 \pm 6 cells) significantly decreased the migration of cells compared with the control $(\mathrm{P}<0.01)$.

The migration of osteoblasts was also investigated using a Transwell assay. The number of migrating cells following treatment with $1 \mathrm{ng} / \mathrm{ml} \mathrm{TGF}-\beta 1$ ( $63 \pm 13$ cells) was significantly increased compared with the NC $(43 \pm 4$ cells; Fig. 5B). Conversely, treatment with $10 \mu \mathrm{M}$ LY294002 with ( $20 \pm 7$ cells) or without TGF- $\beta 1(24 \pm 8$ cells) significantly reduced the number of migrating cells compared with the control $(\mathrm{P}<0.05)$.

PI3K/AKT signalling mediates the TGF- $\beta 1$-induced expression of genes associated with osteogenesis and migration. The mechanisms underlying the effects of TGF- $\beta 1$ and 


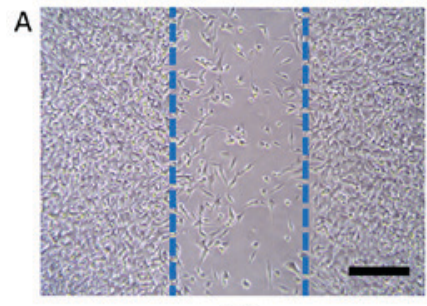

NC

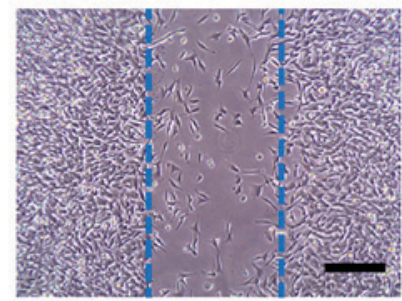

LY

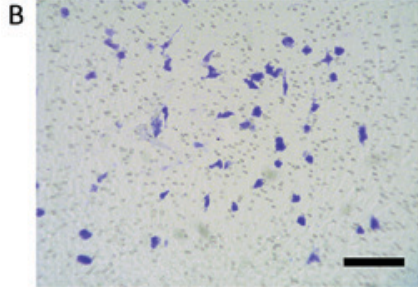

NC

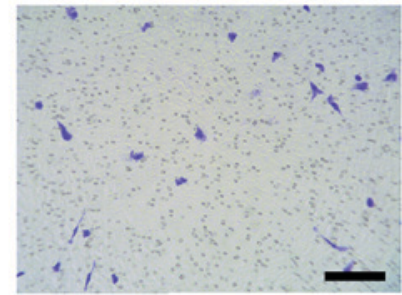

LY

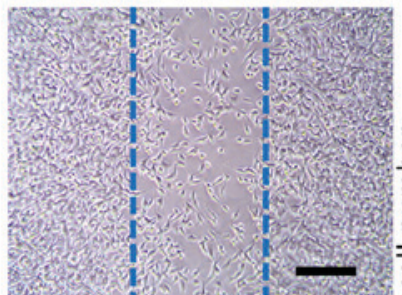

TGF- $\beta 1$

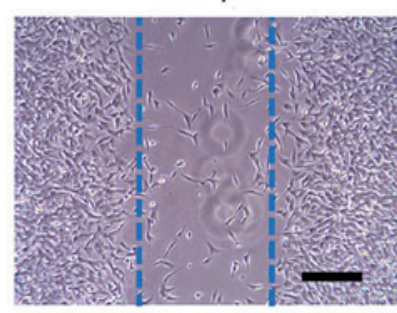

TGF- $\beta 1+L Y$

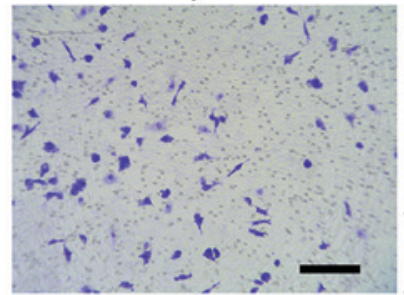

TGF- $\beta 1$

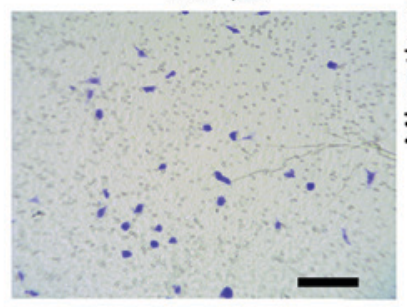

TGF- $\beta 1+L Y$

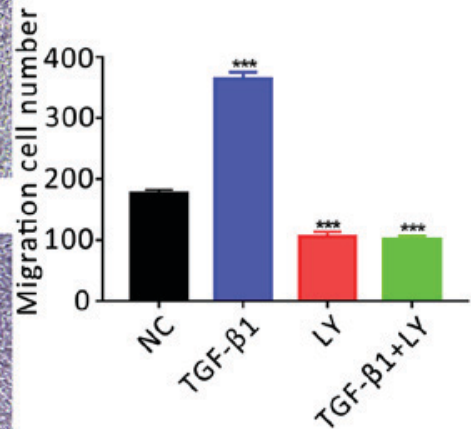

Figure 5. Effects of TGF- $\beta 1$ on the motility of human osteoblasts are dependent upon PI3K/AKT signalling. (A) Migration of hFOB1.19 human osteoblasts treated for $24 \mathrm{~h}$ with $1 \mathrm{ng} / \mathrm{ml} \mathrm{TGF}-\beta 1$ and/or $10 \mu \mathrm{M} \mathrm{LY}$, a PI3K/AKT inhibitor, as determined by a scratch-wound assay. The number of cells entering the wound indicated the migration of cells. (B) Migration of osteoblasts treated for $24 \mathrm{~h}$ with $1 \mathrm{ng} / \mathrm{ml}$ TGF- $\beta 1$ and/or $10 \mu \mathrm{M}$ LY, as determined by a Transwell assay. Scale bar, $200 \mu \mathrm{m}$. Data are presented as the mean \pm standard deviation. ${ }^{*} \mathrm{P}<0.05,{ }^{* * *} \mathrm{P}<0.01$ and ${ }^{* * * *} \mathrm{P}<0.001$ vs. NC. AKT, protein kinase B; LY, LY294002; $\mathrm{NC}$, negative control; PI3K, phosphatidylinositol 3-kinase; TGF- $\beta 1$, transforming growth factor $\beta 1$.

PI3K/AKT signalling on the function of osteoblasts were investigated by determining the mRNA expression of genes associated with the osteogenesis, migration and chemotaxis of cells (Runx2, Osterix, OPN, OCN, MMP-2 and MMP-9). Cells were separated into four groups: The NC; treatment with $1 \mathrm{ng} / \mathrm{ml}$ TGF- $\beta 1$; treatment with $10 \mu \mathrm{M}$ LY294002 combined with TGF- $\beta 1$, and LY294002 treatment alone. It was demonstrated that TGF- $\beta 1$ treatment significantly upregulated the expression of osteogenesis-associated (Runx2, Osterix, OPN and OCN) and migration-associated genes (MMP-2 and MMP-9) compared with the NC (Fig. 6). Conversely, inhibition of the PI3K/AKT signalling pathway significantly downregulated the expression of the aforementioned genes. The results indicated that TGF- $\beta 1$ promoted the migration and mineralisation of osteoblasts in a PI3K/AKT-dependent manner.

Mechanisms underlying the PI3K/AKT/mTOR/S6K1 signalling pathway-dependent effects of TGF- $\beta 1$ on hFOB1.19 osteoblasts. The involvement of mTOR/S6K1 signalling downstream of PI3K/AKT in the osteogenesis and migration of osteoblasts was investigated. Cells were separated into three treatment groups: $1 \mathrm{ng} / \mathrm{ml} \mathrm{TGF}-\beta 1 ; 1 \mathrm{ng} / \mathrm{ml}$ TGF- $\beta 1$ plus $10 \mu \mathrm{M} \mathrm{LY} 294002$, and $1 \mathrm{ng} / \mathrm{ml} \mathrm{TGF}-\beta 1$ plus $100 \mathrm{nM}$ rapamycin (an inhibitor of mTOR/S6K1 signalling). As presented in Fig. 7, inhibition of the mTOR/S6K1 signalling pathway with rapamycin significantly decreased the activity of ALP in osteoblasts and $\mathrm{Ca}^{2+}$ deposition compared with the TGF- $\beta 1$ group $(\mathrm{P}<0.001)$. Similar effects were observed on the motility of cells following treatment with LY294002 or rapamycin compared with TGF- $\beta 1$ treatment alone (Fig. 8). Additionally, treatment with LY294002 or rapamycin significantly downregulated the mRNA expression of migration- and osteogenesis-associated genes compared with TGF- $\beta 1$ treatment alone (Fig. 9). Finally, western blotting was performed to investigate the effects of $1 \mathrm{ng} / \mathrm{ml}$ TGF- $\beta 1$ on PI3K/AKT/mTOR signalling. It was demonstrated that TGF- $\beta 1$ markedly increased the phosphorylation of PI3K, AKT and mTOR compared with the NC group (Fig. 10). The results suggested that the effects of TGF- $\beta 1$ on the osteogenesis and mineralisation osteoblast were mediated 

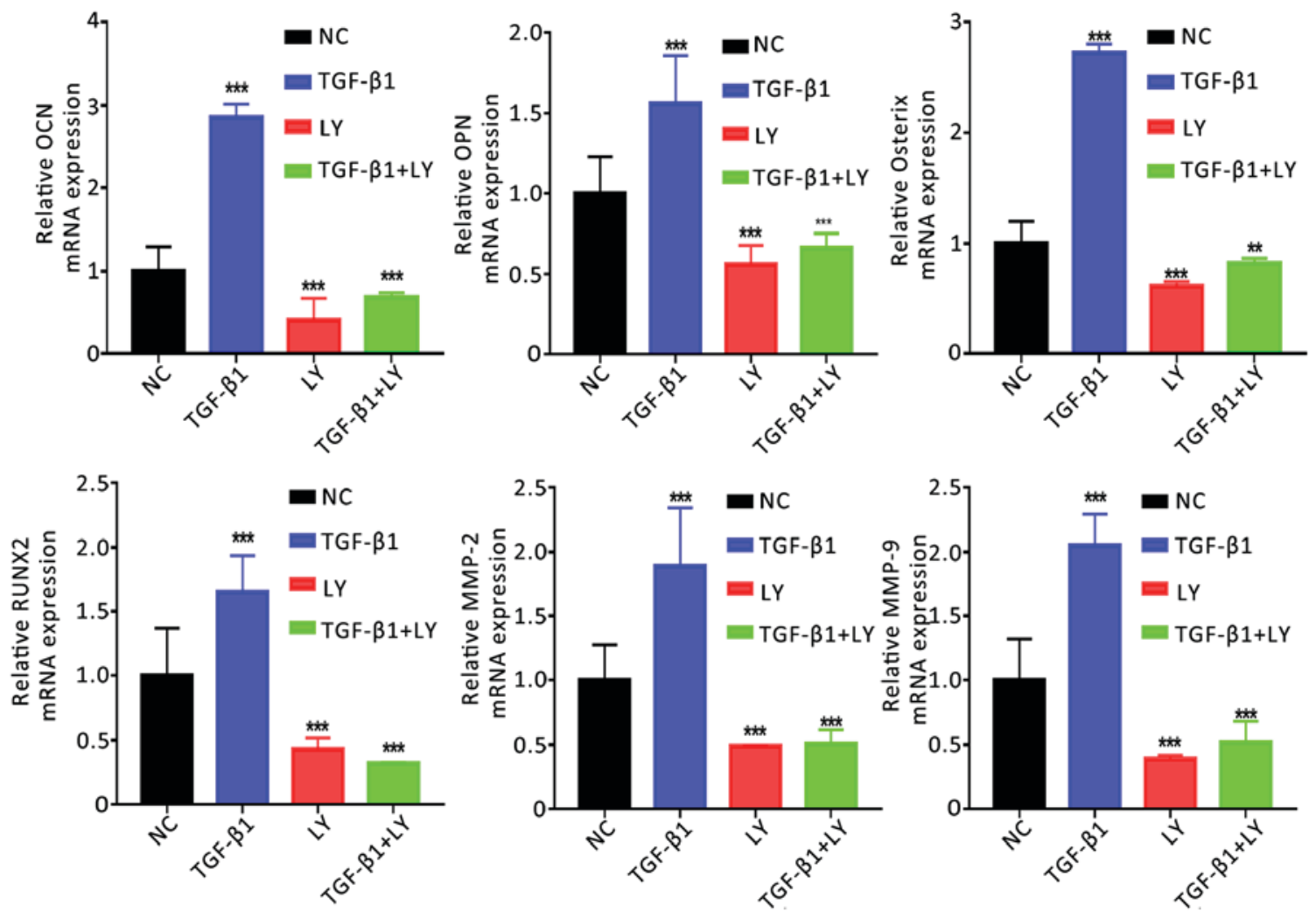

Figure 6. Effects of TGF- $\beta 1$ and inhibition of the PI3K/AKT pathway on the expression of osteogenic and migration-associated genes. Expression of osteogenic (OCN, OPN, Osterix and RUNX2) and migration-associated (MMP2 and MMP9) genes following treatment for 14 days with $1 \mathrm{ng} / \mathrm{ml} \mathrm{TGF-} \beta 1 \mathrm{and} / \mathrm{or} 10 \mu \mathrm{M}$ LY, a PI3K/AKT inhibitor, as determined by reverse transcription-quantitative polymerase chain reaction. Data are presented as the mean \pm standard deviation. ${ }^{* *} \mathrm{P}<0.01,{ }^{* * *} \mathrm{P}<0.001$ vs. NC. AKT, protein kinase B; LY, LY294002; MMP, matrix metalloproteinase; NC, negative control; OCN, osteocalcin; OPN, osteopontin; Osterix, transcription factor Sp7; PI3K, phosphatidylinositol 3-kinase; RUNX2, Runt-related transcription factor 2; TGF- $\beta 1$, transforming growth factor $\beta 1$.

via $\mathrm{mTOR} / \mathrm{S} 6 \mathrm{~K} 1$ signalling downstream of the PI3K/AKT signalling pathway.

\section{Discussion}

Bone tissue engineering is frequently used in the repair and regeneration process of bone injury (32). Further investigation is required to identify novel cytokines, and develop materials and seed cells for improved engineering. Cytokines serve important roles in immune responses, and the proliferation, chemotaxis and differentiation of cells $(33,34)$. TGF- $\beta 1$ was hypothesized to be a potential candidate for the treatment of bone injury; previous studies reported that TGF- $\beta 1$ was a key regulator of bone remodelling and regeneration (35), and stimulated the proliferation of osteoblasts and regulated the function of osteoclasts (36).

Unlike pathways including the MAPK, Wnt, Notch and PI3K signalling pathways, TGF- $\beta 1$ regulates the biological activity of osteoblasts via a variety of mechanisms; this may explain the complexity of its effects on cells $(23,37)$. The cellular concentration of TGF- $\beta 1$ affects the activity of cells; for example, low concentrations promote cell proliferation, whereas opposing effects are observed with high concentrations (38). In the present study, hFOB1.19 osteoblasts were treated with various concentrations of TGF- $\beta 1$, and the effects on proliferation, osteoinduction and migration were investigated. CCK-8 and flow cytometry assays revealed that the proliferation of osteoblasts was most notably increased following treatment with 1 and $2 \mathrm{ng} / \mathrm{ml}$ TGF- $\beta 1$, compared with $0.5,5$ and $10 \mathrm{ng} / \mathrm{ml}$; however, no significant difference was reported between 1 and $2 \mathrm{ng} / \mathrm{ml}$. Therefore, the proliferation of osteoblasts was affected by the concentration of TGF- $\beta 1$ in a non-linear manner. Additionally, the effects of this concentration gradient on osteogenic induction and migration were determined. ALP and Alizarin red S staining revealed that 1 and $2 \mathrm{ng} / \mathrm{ml}$ TGF- $\beta 1$ markedly increased the activity of ALP in osteoblasts and levels of $\mathrm{Ca}^{2+}$ deposition, compared with 0.5 and $>5 \mathrm{mg} / \mathrm{ml}$ TGF- $\beta 1$. Furthermore, scratch-wound and Transwell assays revealed that TGF- $\beta 1$ most notably increased the motility of osteoblasts at 1 and $2 \mathrm{ng} / \mathrm{ml}$. These findings indicated that a basal concentration of $1 \mathrm{ng} / \mathrm{ml}$ may be optimal for inducing the biological effects of TGF- $\beta 1$ on human osteoblasts.

The mineralisation of osteoblasts is important for regeneration during bone repair; improvements in osteogenesis and mineralisation promote bone repair (5). It has been reported that TGF- $\beta 1$ induces osteoblast differentiation $(39,40)$. Cell differentiation mediated by TGF- $\beta 1$ may be regulated by Smad-dependent and -independent pathways (41); however, the effects and involvement of Smad-independent signalling pathways in the TGF- $\beta 1$-mediated differentiation of osteoblasts require further investigation. PI3K is an important signalling molecule for numerous cellular activities $(41,42)$. PI3K catalyses the phosphorylation 


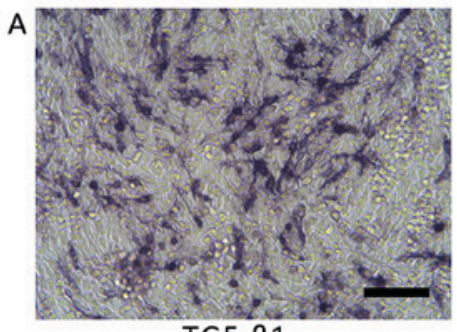

TGF- $\beta 1$

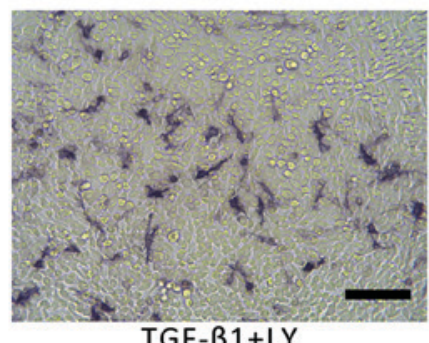

TGF- $\beta 1+L Y$

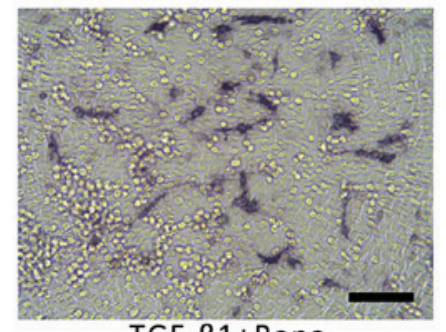

TGF- $\beta 1+$ Rapa

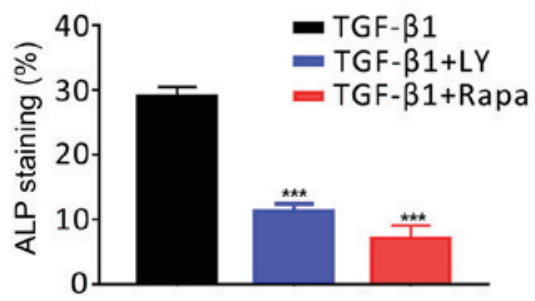

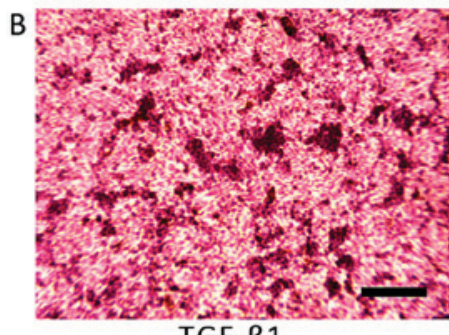

TGF- $\beta 1$

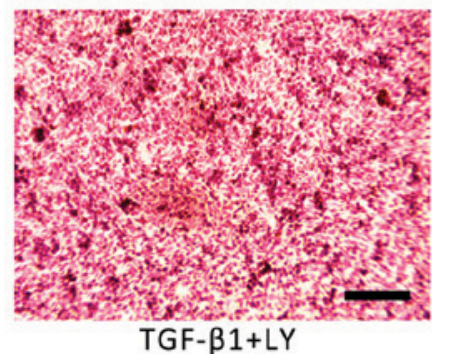

TGF- $\beta 1+L Y$

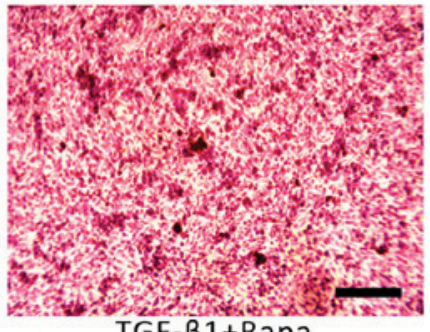

TGF- $\beta 1+R a p a$

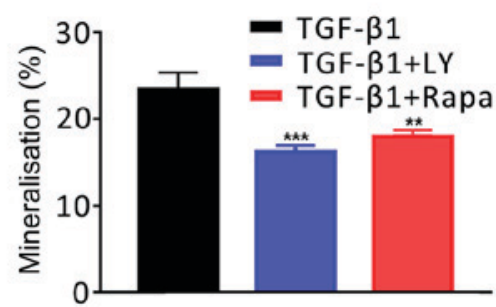

Figure 7. Effects of the inhibition of PI3K/AKT and mTOR/S6K1 signalling on TGF- $\beta 1$-mediated osteogenic induction. (A) Effects of treatment for 7 days with $1 \mathrm{ng} / \mathrm{ml}$ TGF- $\beta 1$ plus $10 \mu \mathrm{M} \mathrm{LY}$, a PI3K/AKT inhibitor, or $100 \mathrm{nM}$ Rapa, an mTOR/S6K1 inhibitor, on the activity of ALP in hFOB1.19 human osteoblasts. ALP-positive cells were stained with 5-bromo-4-chloro-3-indolyl-phosphate/nitro blue tetrazolium. (B) $\mathrm{Ca}^{2+}$ deposits following treatment of osteoblasts for 14 days with $1 \mathrm{ng} / \mathrm{ml}$ TGF- $\beta 1$ plus $10 \mu \mathrm{M} \mathrm{LY}$ or $100 \mathrm{nM}$ Rapa, as identified by Alizarin red S staining. Scale bar, $200 \mu \mathrm{m}$. Data are presented as the mean \pm standard deviation. ${ }^{* * *} \mathrm{P}<0.01$ and ${ }^{* * * *} \mathrm{P}<0.001$ vs. TGF- $\beta 1$. AKT, protein kinase B; ALP, alkaline phosphatase; LY, LY294002; mTOR, mammalian target of rapamycin; NC, negative control; PI3K, phosphatidylinositol 3-kinase; Rapa, rapamycin; S6K1, S6 kinase 1; TGF- $\beta 1$, transforming growth factor $\beta 1$.

of the D3 hydroxyl of phosphatidylinositol to produce phosphatidylinositol-3,4,5-trisphosphate, which binds to phosphoinositide-dependent kinase and the intracellular pleckstrin homology domain of AKT (42). Activation of AKT regulates the proliferation, differentiation, apoptosis and migration of cells (43). TGF- $\beta 1$ induces various biological effects on cells via PI3K/AKT signalling (44). The activity of ALP and the synthesis of extracellular matrix calcium ion deposits are important indicators of osteoblast ossification and mineralisation. In the present study, the effects of TGF- $\beta 1$ on the ossification and mineralisation of osteoblasts were evaluated by Alizarin red and ALP staining. It was demonstrated that the expression of ALP and the number of mineralised nodules were significantly increased following treatment with $1 \mathrm{ng} / \mathrm{ml}$ TGF- $\beta 1$; however, treatment with the PI3K/AKT blocker LY294002 induced opposing effects, regardless of TGF- $\beta 1$ treatment. The results indicated that the effects of TGF- $\beta 1$ on ALP activity and the mineralisation of osteoblasts may involve the PI3K/AKT signalling pathway.

The migration of osteoblasts to a damaged area serves an important role in the repair of bone injury, as it promotes bone regeneration $(45,46)$. A previous study reported that TGF- $\beta 1$ upregulated the expression of chemokine $\mathrm{C}-\mathrm{X}-\mathrm{C}$ motif ligand 16 in osteoblasts to stimulate the migration of cells (47). In the present study, the effects of TGF- $\beta 1$ on the migration of osteoblasts were evaluated. It was demonstrated that cells treated with $1 \mathrm{ng} / \mathrm{ml}$ TGF- $\beta 1$ exhibited significantly increased motility compared with the NC. Conversely, inhibition of the $\mathrm{PI} 3 \mathrm{~K} / \mathrm{AKT}$ signalling pathway reduced the migration of osteoblasts, indicating that the effects of TGF- $\beta 1$ on the motility of osteoblasts involved PI3K/AKT.

To further investigate the effects of TGF- $\beta 1$ on the ossification and migration of osteoblasts, the mRNA expression of associated genes was investigated, including Runx2, OPN, OCN, Osterix, MMP-2 and MMP-9. Runx2 is 


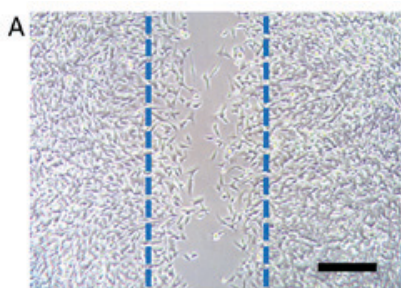

TGF- $\beta 1$

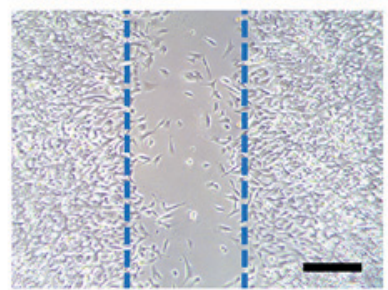

TGF- $\beta 1+L Y$

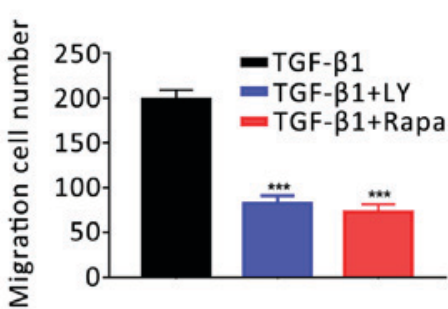

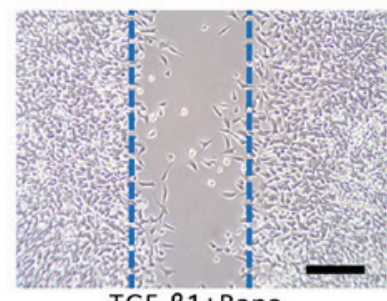

TGF- $\beta 1+R a p a$
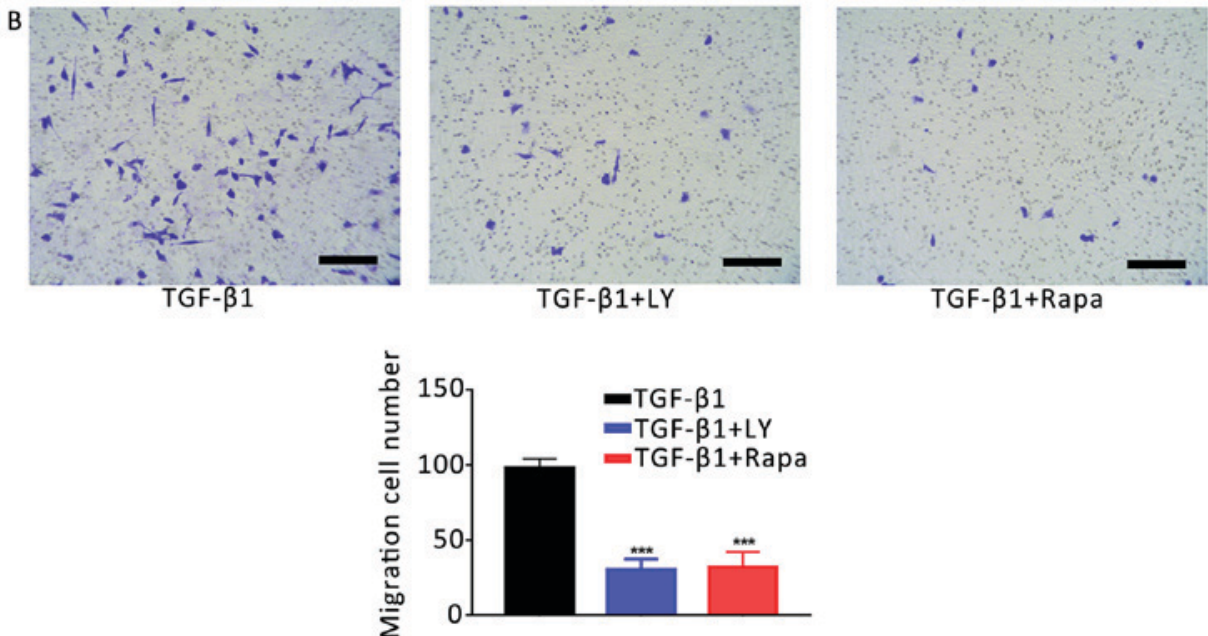

Figure 8. Effects of the inhibition of PI3K/AKT and mTOR/S6K1 signalling on the TGF- $\beta 1$-induced increase in osteoblast motility. (A) Migration of hFOB1.19 human osteoblasts treated for $24 \mathrm{~h}$ with $1 \mathrm{ng} / \mathrm{ml}$ TGF- $\beta 1$ plus $10 \mu \mathrm{M} \mathrm{LY}$, a PI3K/AKT inhibitor, or $100 \mathrm{nM}$ Rapa, an mTOR/S6K1 inhibitor; as determined by a scratch-wound assay. The number of cells entering the wound indicated the migration of cells. (B) Migration of osteoblasts treated for $24 \mathrm{~h}$ with $1 \mathrm{ng} / \mathrm{ml}$ TGF- $\beta 1$ plus $10 \mu \mathrm{M}$ LY or $100 \mathrm{nM} \mathrm{Rapa,} \mathrm{as} \mathrm{determined} \mathrm{by} \mathrm{a} \mathrm{Transwell} \mathrm{assay.} \mathrm{Scale} \mathrm{bar,} 200 \mu \mathrm{m}$. Data are presented as the mean \pm standard deviation. ${ }^{* * * *} \mathrm{P}<0.001$ vs. TGF- $\beta 1$. AKT, protein kinase B; LY, LY294002; mTOR, mammalian target of rapamycin; NC, negative control; PI3K, phosphatidylinositol 3-kinase; Rapa, rapamycin; S6K1, S6 kinase 1; TGF- $\beta 1$, transforming growth factor $\beta 1$.

a transcription factor specific to osteoblast differentiation, and is the earliest and most specific marker gene during bone formation $(48,49)$. It has been reported that the Runx2 gene activates the transcription and expression of OCN, OPN, bone sialoprotein and type I collagen by binding to the cis-acting elements of osteoblasts (50). OPN serves an important role in the mineralisation and absorption of bone matrix (51). OCN is an important component of the extracellular matrix and is regarded as a specific marker of the bone turnover process (52); when OCN is in an inactive state, it directly affects the formation, absorption and mineralisation of bone (53). The zinc finger protein Osterix is considered to be an important regulator of osteoblast differentiation and maturation (54). The MMP family serves roles in the invasion and metastasis of cells; MMP-2 and MMP-9 are involved in bone remodelling and regeneration (55). In the present study, the expression of osteogenic (Runx2, OPN, OCN and Osterix) and migration-associated genes (MMP2 and MMP9) was significantly upregulated following treatment with $1 \mathrm{ng} / \mathrm{ml}$
TGF- $\beta 1$. In addition, by blocking the PI3K/AKT signalling pathway, the expression of these genes was downregulated. These findings indicated that TGF- $\beta 1$ promoted the osteogenesis and migration of osteoblasts via the upregulation of associated genes in a PI3K/AKT-dependent manner; however, in addition to TGF- $\beta 1$, there may be other signals regulating the PI3K/AKT pathway in osteoblasts, as treatment with LY294002 significantly downregulated gene expression compared with the NC.

mTOR is a target of rapamycin and is downstream of the PI3K/AKT signalling pathway. Activated AKT directly phosphorylates the Ser2448 site of mTOR (56); S6K1 is one of the main targets downstream of mTOR that is induced following the activation of mTOR (57). mTOR/S6K1 signalling serves important roles in the biological processes of various cells, including DNA replication, mRNA translation, and the synthesis of proteins and lipids to regulate the growth, survival, migration, and differentiation of cells $(58,59)$. Luo et al $(30)$ reported that blocking the AKT 

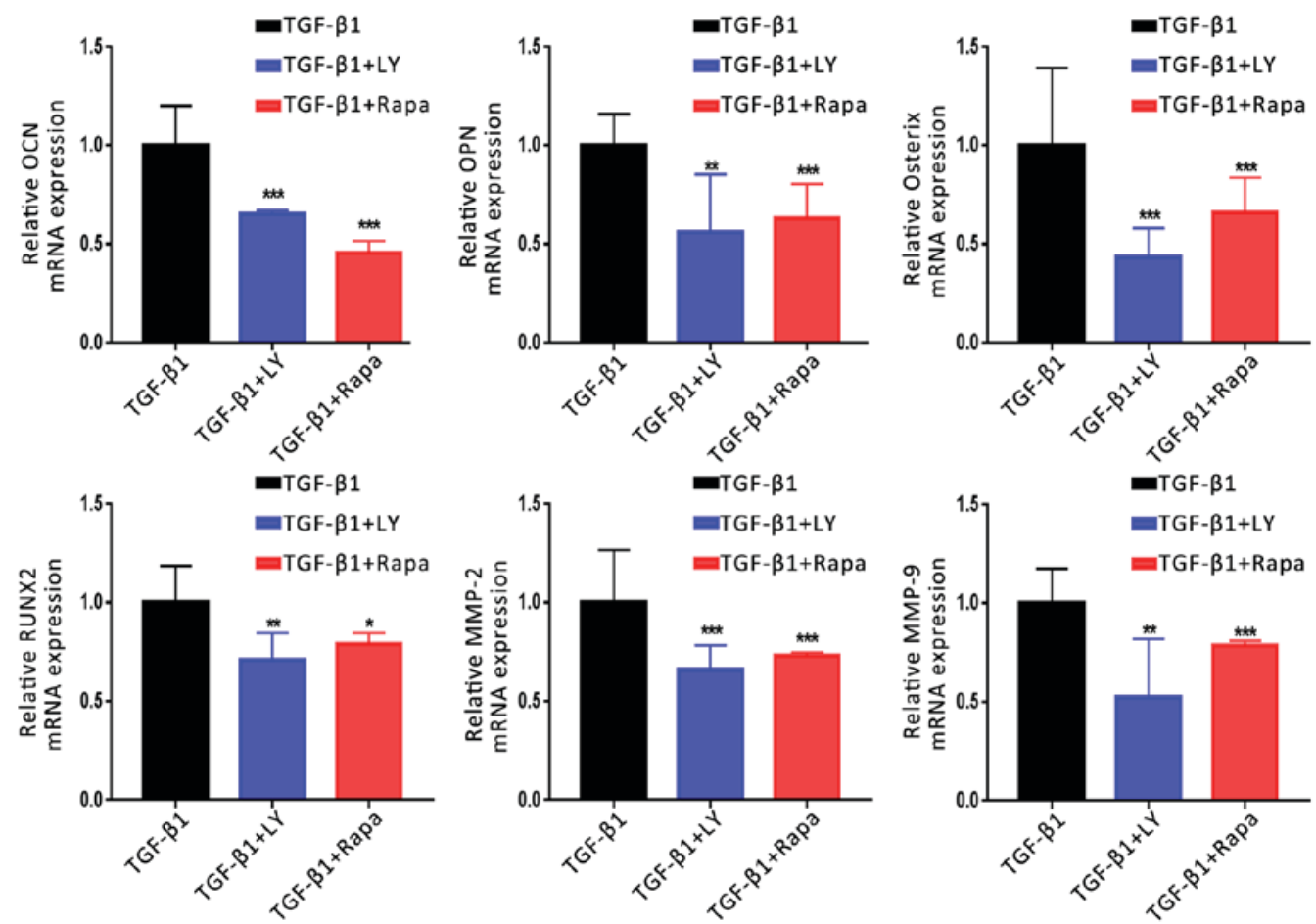

Figure 9. Effects of the inhibition of PI3K/AKT and mTOR/S6K1 signalling on the TGF- $\beta 1$-induced upregulation of osteogenic and migration-associated genes. Expression of osteogenic (OCN, OPN, Osterix and RUNX2) and migration-associated (MMP2 and MMP9) genes following treatment for 14 days with $1 \mathrm{ng} / \mathrm{ml}$ TGF- $\beta 1$ plus $10 \mu \mathrm{M} \mathrm{LY}$, a PI3K/AKT inhibitor, or $100 \mathrm{nM}$ Rapa, an mTOR/S6K1 inhibitor, as determined by reverse transcription-quantitative polymerase chain reaction. Data are presented as the mean \pm standard deviation. ${ }^{*} \mathrm{P}<0.05,{ }^{* *} \mathrm{P}<0.01,{ }^{* * *} \mathrm{P}<0.001$ vs. TGF- $\beta 1$. AKT, protein kinase $\mathrm{B} ; \mathrm{LY}, \mathrm{LY} 294002$; MMP, matrix metalloproteinase; mTOR, mammalian target of rapamycin; NC, negative control; OCN, osteocalcin; OPN, osteopontin; Osterix, transcription factor Sp7; PI3K, phosphatidylinositol 3-kinase; Rapa, rapamycin; RUNX2, Runt-related transcription factor 2; S6K1, S6 kinase 1; TGF- $\beta 1$, transforming growth factor $\beta 1$.

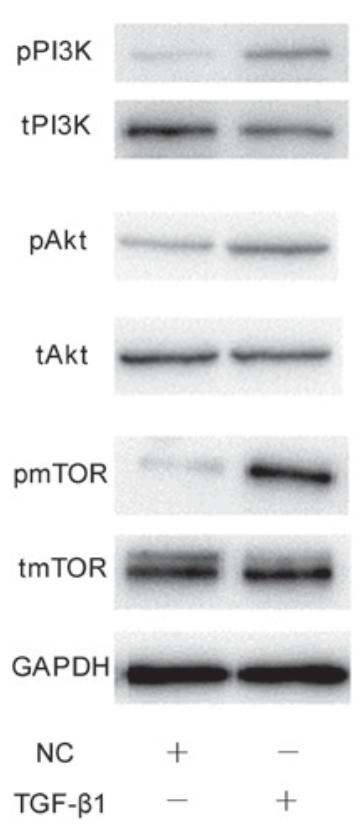

Figure 10. Phosphorylation of PI3K/AKT/mTOR proteins in osteoblasts treated with TGF- $\beta 1$. Representative western blot of t- and p-PI3K, AKT and mTOR expression following treatment $1 \mathrm{ng} / \mathrm{ml}$ TGF- $\beta 1$ for $24 \mathrm{~h}$. AKT, protein kinase $\mathrm{B}$; mTOR, mammalian target of rapamycin; NC, negative control; p, phosphorylated; PI3K, phosphatidylinositol 3-kinase; t, total; TGF- $\beta 1$, transforming growth factor $\beta 1$.

signalling pathway decreased mTOR/S6K1 signalling, and reduced the ability of osteocytes to differentiate and

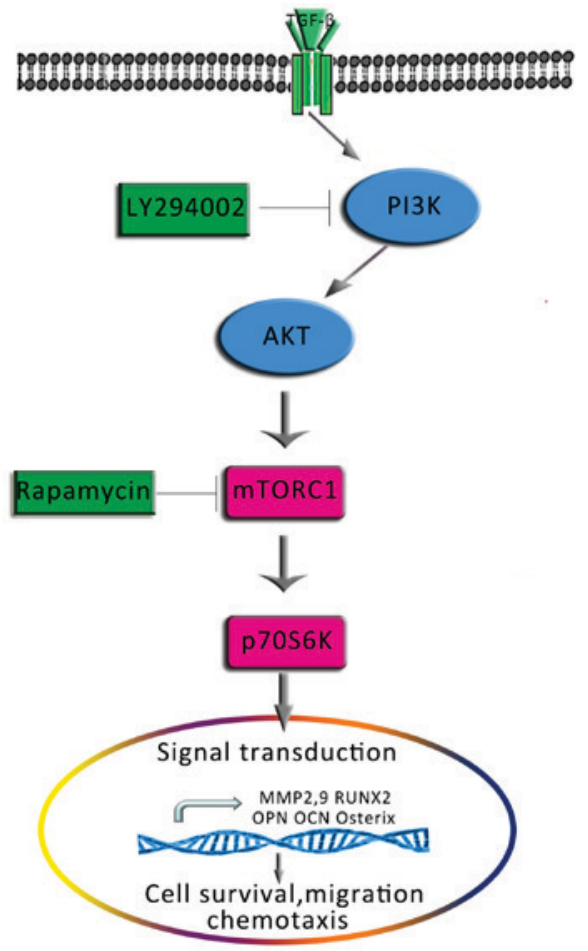

Figure 11. Proposed schematic depicting the signalling pathway via which TGF- $\beta 1$ promotes the osteogenesis and migration of osteoblasts. AKT, protein kinase B; MMP, matrix metalloproteinase; mTOR, mammalian target of rapamycin; OCN, osteocalcin; OPN, osteopontin; Osterix, transcription factor Sp7; p70S6K, p70-S6 kinase 1; PI3K, phosphatidylinositol 3-kinase; Runx2, Runt-related transcription factor 2 ; TGF- $\beta 1$, transforming growth factor $\beta 1$. 
proliferate. In the present study, treatment with TGF- $\beta 1$ was combined with an mTOR/S6K1 inhibitor, rapamycin, to investigate the involvement of mTOR/S6K1 in the effects of TGF- $\beta 1$. Similar to PI3K/AKT blockade, treatment with rapamycin significantly decreased ALP activity, the number of mineralised nodules and the motility of osteoblasts compared with TGF- $\beta 1$ treatment alone. Furthermore, analysis of mRNA expression in osteoblasts revealed that rapamycin suppressed the TGF- $\beta 1$-induced upregulation of osteogenic and migration-associated genes. The results indicated that the PI3K/AKT-mediated effects of TGF- $\beta 1$ on osteoblast osteogenesis and mineralisation also involved the mTOR/S6K1 pathway downstream of PI3K/AKT (Fig. 11).

In conclusion, it was demonstrated that TGF- $\beta 1$ promoted the survival, osteogenic differentiation and migration of human hFOB1.19 osteoblasts. Additionally, it was revealed that TGF- $\beta 1$ induced these effects via the PI3K/AKT/mTOR/S6K1 signalling pathway. These findings indicated a potential role for TGF- $\beta 1$ in the field of bone tissue engineering and provided novel insight into the mechanisms for application in bone injury repair in the future.

\section{Acknowledgements}

Not applicable.

\section{Funding}

The present study was supported by grants from the class general financial grant from the China Postdoctoral Science Foundation (grant nos. 2017M620099 and 171478), the National Natural Scientific Foundation of China (grant no. 81672139), the Science and Technology Research Foundation of Liaoning Provincial Department of Education (grant no. L2015034), the Scientific Research Foundation for the PhD, Liaoning Provincial Department of Science and Technology (grant no. 201601305), and the Scientific Research Foundation for Overseas Students, Ministry of Human Resources and Social Security of the People's Republic of China (grant no. 2016-176).

\section{Availability of data and materials}

All data generated or analyzed during the present study are included in this published article.

\section{Authors' contributions}

$\mathrm{XZ}$ and $\mathrm{ZZ}$ contributed to the conception and design of the study, acquired and analyzed the data and drafted the manuscript. DZ contributed to the conception and design of the study, and revised the article critically for important intellectual content. BL, BW, WY, JL, XY, FC, GZ, YZ and YL contributed to the design of the study, revised the article and approved the final manuscript.

\section{Ethics approval and consent to participate}

Not applicable.

\section{Patients consent for publication}

Not applicable.

\section{Competing interests}

The authors declare that they have no competing interests.

\section{References}

1. Wei X, Zhao D, Wang B, Wang W, Kang K, Xie H, Liu B, Zhang $\mathrm{X}$, Zhang $\mathrm{J}$ and Yang Z: Tantalum coating of porous carbon scaffold supplemented with autologous bone marrow stromal stem cells for bone regeneration in vitro and in vivo. Exp Biol Med (Maywood) 241: 592-602, 2016.

2. Su N, Gao PL, Wang K, Wang JY, Zhong Y and Luo Y: Fibrous scaffolds potentiate the paracrine function of mesenchymal stem cells: A new dimension in cell-material interaction. Biomaterials 141: 74-85, 2017.

3. Xia Y, Sun J, Zhao L, Zhang F, Liang XJ, Guo Y, Weir MD, Reynolds MA, Gu N and Xu HHK: Magnetic field and nano-scaffolds with stem cells to enhance bone regeneration. Biomaterials 183: 151-170, 2018.

4. Hallam P, Haddad F and Cobb J: Pain in the well-fixed, aseptic titanium hip replacement. The role of corrosion. J Bone Joint Surg Br 86: 27-30, 2004.

5. Zhang X, Zu H, Zhao D, Yang K, Tian S, Yu X, Lu F, Liu B, Yu X Wang B, et al: Ion channel functional protein kinase TRPM7 regulates $\mathrm{Mg}$ ions to promote the osteoinduction of human osteoblast via PI3K pathway: In vitro simulation of the bone-repairing effect of Mg-based alloy implant. Acta Biomater 63: 369-382, 2017.

6. Lin D, Zuo S, Li L, Wang L and Lian K: Treatment of neglected femoral neck fractures using the modified dynamic hip screw with autogenous bone and bone morphogenetic protein-2 composite materials grafting. Indian J Orthop 49: 342-346, 2015.

7. Moore NM, Lin NJ, Gallant ND and Becker ML: Synergistic enhancement of human bone marrow stromal cell proliferation and osteogenic differentiation on BMP-2-derived and RGD peptide concentration gradients. Acta Biomater 7: 2091-2100, 2011.

8. Piek E, Sleumer LS, van Someren EP, Heuver L, de Haan JR, de Grijs I, Gilissen C, Hendriks JM, van Ravestein-van Os RI, Bauerschmidt S, et al: Osteo-transcriptomics of human mesenchymal stem cells: Accelerated gene expression and osteoblast differentiation induced by vitamin D reveals c-MYC as an enhancer of BMP2-induced osteogenesis. Bone 46: 613-627, 2010.

9. Poh CK, Shi Z, Lim TY, Neoh KG and Wang W: The effect of VEGF functionalization of titanium on endothelial cells in vitro. Biomaterials 31: 1578-1585, 2010.

10. Geiger F, Beverungen M, Lorenz H, Wieland J, Fehr M and Kasten P: Bone substitute effect on vascularization and bone remodeling after application of phVEGF165 transfected BMSC. J Funct Biomater 3: 313-326, 2012.

11. Yu H, Zeng X, Deng C, Shi C, Ai J and Leng W: Exogenous VEGF introduced by bioceramic composite materials promotes the restoration of bone defect in rabbits. Biomed Pharmacother 98: 325-332, 2018.

12. Ueland T, Lekva T, Otterdal K, Dahl TB, Olarescu NC, Jørgensen AP, Fougner KJ, Brixen K, Aukrust P and Bollerslev J: Increased serum and bone matrix levels of transforming growth factor $\{$ beta\} 1 in patients with GH deficiency in response to GH treatment. Eur J Endocrinol 165: 393-400, 2011.

13. Bonewald LF and Dallas SL: Role of active and latent transforming growth factor beta in bone formation. J Cell Biochem 55: 350-357, 1994.

14. Zhao Y, Li Y, Gao Y, Yuan M, Manthari RK, Wang J and Wang J: TGF- $\beta 1$ acts as mediator in fluoride-induced autophagy in the mouse osteoblast cells. Food Chem Toxicol 115: 26-33, 2018.

15. Siegel PM and Massagué J: Cytostatic and apoptotic actions of TGF-beta in homeostasis and cancer. Nat Rev Cancer 3: 807-821, 2003.

16. Lind M: Growth factor stimulation of bone healing. Effects on osteoblasts, osteomies, and implants fixation. Acta Orthop Scand Suppl 283: 2-37, 1998 . 
17. Duan X, Liu J, Zheng X, Wang Z, Zhang Y, Hao Y, Yang T and Deng H: Deficiency of ATP6V1H causes bone loss by inhibiting bone resorption and bone formation through the TGF- $\beta 1$ pathway. Theranostics 6: 2183-2195, 2016.

18. Marcelli C, Yates AJ and Mundy GR: In vivo effects of human recombinant transforming growth factor beta on bone turnover in normal mice. J Bone Miner Res 5: 1087-1096, 1990.

19. Chen LJ, Chen C, Qiao XY, Yu K, Xie LZ, Cao J, Liu BL and Yan Y: Effect of porous titanium coated with IGF-1 and TGF- $\beta$ loaded gelatin microsphere on function of MG63 cells. Transact Nonferr Metals Soc China 25: 2974-2985, 2015.

20. Lamberg A, Schmidmaier G, Søballe K and Elmengaard B: Locally delivered TGF-beta1 and IGF-1 enhance the fixation of titanium implants: A study in dogs. Acta Orthop 77: 799-805, 2006.

21. Feng XH and Derynck R: Specificity and versatility in tgf-beta signaling through Smads. Annu Rev Cell Dev Biol 21: 659-693, 2005.

22. Karst M, Gorny G, Galvin RJ and Oursler MJ: Roles of stromal cell RANKL, OPG, and M-CSF expression in biphasic TGF-beta regulation of osteoclast differentiation. J Cell Physiol 200: 99-106, 2004

23. Chen G, Deng C and Li YP: TGF- $\beta$ and BMP signaling in osteoblast differentiation and bone formation. Int J Biol Sci 8: 272-288, 2012.

24. Kang JS, Alliston T, Delston R and Derynck R: Repression of Runx 2 function by TGF-beta through recruitment of class II histone deacetylases by Smad3. EMBO J 24: 2543-2555, 2005.

25. Xie F, Ling L, van Dam H, Zhou F and Zhang L: TGF- $\beta$ signaling in cancer metastasis. Acta Biochim Biophys Sin (Shanghai) 50 : 121-132, 2018

26. Wang J, Ma XY,Feng YF, Ma ZS, Ma TC, Zhang Y, Li X, Wang L and Lei W: Magnesium ions promote the biological behaviour of rat calvarial osteoblasts by activating the PI3K/Akt signalling pathway. Biol Trace Elem Res 179: 284-293, 2017.

27. Bertacchini J, Heidari N, Mediani L, Capitani S, Shahjahani M, Ahmadzadeh A and Saki N: Targeting PI3K/AKT/mTOR network for treatment of leukemia. Cell Mol Life Sci 72: 2337-2347, 2015

28. Manfredi GI, Dicitore A, Gaudenzi G, Caraglia M, Persani L and Vitale G: PI3K/Akt/mTOR signaling in medullary thyroid cancer: A promising molecular target for cancer therapy. Endocrine 48: 363-370, 2015

29. Golub EE, Harrison G, Taylor AG, Camper S and Shapiro IM The role of alkaline phosphatase in cartilage mineralization. Bone Miner 17: 273-278, 1992.

30. Luo G, Xu B and Huang Y: Icariside II promotes the osteogenic differentiation of canine bone marrow mesenchymal stem cells via the PI3K/AKT/mTOR/S6K1 signaling pathways. Am J Transl Res 9: 2077-2087, 2017.

31. Livak KJ and Schmittgen TD: Analysis of relative gene expression data using real-time quantitative PCR and the 2(-Delta Delta C(T)) method. Methods 25: 402-408, 2001

32. Chen Q, Zhu C and Thouas GA: Progress and challenges in biomaterials used for bone tissue engineering: Bioactive glasses and elastomeric composites. Prog Biomater 1: 2, 2012

33. Chen X, Lu J, Ji Y, Hong A and Xie Q: Cytokines in osteoblast-conditioned medium promote the migration of breast cancer cells. Tumour Biol 35: 791-798, 2014

34. Hughes FJ, Turner W, Belibasakis G and Martuscelli G: Effects of growth factors and cytokines on osteoblast differentiation. Periodontol 2000 41: 48-72, 2006.

35. Janssens K, ten Dijke P, Janssens S and Van Hul W: Transforming growth factor-betal to the bone. Endocr Rev 26: 743-774, 2005

36. Ota K, Quint P, Ruan M, Pederson L, Westendorf JJ, Khosla S and Oursler MJ: TGF- $\beta$ induces Wnt10b in osteoclasts from female mice to enhance coupling to osteoblasts. Endocrinology 154 3745-3752, 2013

37. Kanaan RA and Kanaan LA: Transforming growth factor beta1, bone connection. Med Sci Monit 12: RA164-RA169, 2006.

38. Wang X, Dong F, Zhang S, Yang W, Yu W, Wang Z, Zhang S, Wang J, Ma S, Wu P, et al: TGF-betal negatively regulates the number and function of hematopoietic stem cells. Stem Cell Reports 11: 274-287, 2018

39. Matsunobu T, Torigoe K, Ishikawa M, de Vega S, Kulkarni AB Iwamoto Y and Yamada Y: Critical roles of the TGF-beta type I receptor ALK5 in perichondrial formation and function, cartilage integrity, and osteoblast differentiation during growth plate development. Dev Biol 332: 325-338, 2009.

40. Ramirez-Yañez GO, Hamlet S, Jonarta A, Seymour GJ and Symons AL: Prostaglandin E2 enhances transforming growth factor-beta 1 and TGF-beta receptors synthesis: An in vivo and in vitro study. Prostaglandins Leukot Essent Fatty Acids 74: $183-192,2006$
41. Cantrell DA: Phosphoinositide 3-kinase signalling pathways J Cell Sci 114: 1439-1445, 2001

42. Cantley LC: The phosphoinositide 3-kinase pathway. Science 296: 1655-1657, 2002.

43. Guntur AR and Rosen CJ: The skeleton: A multi-functional complex organ: New insights into osteoblasts and their role in bone formation: The central role of PI3Kinase. J Endocrinol 211: 123-130, 2011.

44. Mukherjee A and Rotwein P: Akt promotes BMP2-mediated osteoblast differentiation and bone development. J Cell Sci 122: 716-726, 2009

45. Kristensen HB, Andersen TL, Marcussen N, Rolighed L and Delaisse JM: Osteoblast recruitment routes in human cancellous bone remodeling. Am J Pathol 184: 778-789, 2014.

46. Maes C, Kobayashi T, Selig MK, Torrekens S, Roth SI, Mackem S, Carmeliet G and Kronenberg HM: Osteoblast precursors, but not mature osteoblasts, move into developing and fractured bones along with invading blood vessels. Dev Cell 19: 329-344, 2010.

47. Ota K, Quint P, Weivoda MM, Ruan M, Pederson L, Westendorf JJ, Khosla S and Oursler MJ: Transforming growth factor beta 1 induces CXCL16 and leukemia inhibitory factor expression in osteoclasts to modulate migration of osteoblast progenitors. Bone 57: 68-75, 2013

48. Fie C, Guo J, Zhao Y, Gu S, Zhao S, Li X and Chang C: Notch-Hes pathway mediates the impaired osteogenic differentiation of bone marrow mesenchymal stromal cells from myelodysplastic syndromes patients through the down-regulation of Runx2. Am J Transl Res 7: 1939-1951, 2015.

49. Kumar Y, Kapoor I, Khan K, Thacker G, Khan MP, Shukla N, Kanaujiya JK, Sanyal S, Chattopadhyay N and Trivedi AK: E3 ubiquitin ligase Fbw7 negatively regulates osteoblast differentiation by targeting Runx 2 for degradation. J Biol Chem 290: 30975-30987, 2015.

50. Gersbach CA, Byers BA,Pavlath GK and García AJ: Runx2/Cbfa1 stimulates transdifferentiation of primary skeletal myoblasts into a mineralizing osteoblastic phenotype. Exp Cell Res 300: 406-417, 2004

51. Creff G, Safi S, Roques J, Michel H, Jeanson A, Solari PL, Basset C, Simoni E, Vidaud C and Den Auwer C: Actinide(IV) deposits on bone: Potential role of the osteopontin-thorium complex. Inorg Chem 55: 29-36, 2016.

52. Schwetz V, Pieber T and Obermayer-Pietsch B: The endocrine role of the skeleton: Background and clinical evidence. Eur J Endocrinol 166: 959-967, 2012.

53. Lee NK, Sowa H, Hinoi E, Ferron M, Ahn JD, Confavreux C, Dacquin R, Mee PJ, McKee MD, Jung DY, et al: Endocrine regulation of energy metabolism by the skeleton. Cell 130: 456-469, 2007.

54. Renn J and Winkler C: Osterix/Sp7 regulates biomineralization of otoliths and bone in medaka (Oryzias latipes). Matrix Biol 34: 193-204, 2014

55. Dong Q, Fu L, Zhao Y, Tan S and Wang E: Derlin-1 overexpression confers poor prognosis in muscle invasive bladder cancer and contributes to chemoresistance and invasion through PI3K/AKT and ERK/MMP signaling. Oncotarget 8: 17059-17069, 2017.

56. Huang J and Manning BD: The TSC1-TSC2 complex: A molecular switchboard controlling cell growth. Biochem J 412: 179-190, 2008

57. Magnuson B, Ekim B and Fingar D: Regulation and function of ribosomal protein S6 kinase (S6K) within mTOR signalling networks. Biochem J 441: 1-21, 2012.

58. Swiech L, Perycz M, Malik A and Jaworski J: Role of mTOR in physiology and pathology of the nervous system. Biochim Biophys Acta 1784: 116-132, 2008.

59. Inoki K, Ouyang H, Li Y and Guan KL: Signaling by target of rapamycin proteins in cell growth control. Microbiol Mol Biol Rev 69: 79-100, 2005.

This work is licensed under a Creative Commons Attribution-NonCommercial-NoDerivatives 4.0 International (CC BY-NC-ND 4.0) License. 